\title{
Effect of grazers and viruses on bacterial community structure and production in two contrasting trophic lakes
}

\author{
Lyria Berdjeb, Thomas Pollet, Isabelle Domaizon and Stéphan Jacquet
}

\begin{abstract}
Background: Over the last 30 years, extensive studies have revealed the crucial roles played by microbes in aquatic ecosystems. It has been shown that bacteria, viruses and protozoan grazers are dominant in terms of abundance and biomass. The frequent interactions between these microbiological compartments are responsible for strong trophic links from dissolved organic matter to higher trophic levels, via heterotrophic bacteria, which form the basis for the important biogeochemical roles of microbial food webs in aquatic ecosystems. To gain a better understanding of the interactions between bacteria, viruses and flagellates in lacustrine ecosystems, we investigated the effect of protistan bacterivory on bacterial abundance, production and structure [determined by $16 \mathrm{~S}$ rRNA PCR-DGGE], and viral abundance and activity of two lakes of contrasting trophic status. Four experiments were conducted in the oligotrophic Lake Annecy and the mesotrophic Lake Bourget over two seasons (early spring vs. summer) using a fractionation approach. In situ dark vs. light incubations were performed to consider the effects of the different treatments in the presence and absence of phototrophic activity.

Results: The presence of grazers (i.e. $<5$ - $\mathrm{mm}$ small eukaryotes) affected viral production positively in all experiments, and the stimulation of viral production (compared to the treatment with no eukaryotic predators) was more variable between lakes than between seasons, with the highest value having been recorded in the mesotrophic lake (+30\%). Viral lysis and grazing activities acted additively to sustain high bacterial production in all experiments. Nevertheless, the stimulation of bacterial production was more variable between seasons than between lakes, with the highest values obtained in summer (+33.5\% and $+37.5 \%$ in Lakes Bourget and Annecy, respectively). The presence of both predators (nanoflagellates and viruses) did not seem to have a clear influence upon bacterial community structure according to the four experiments.

Conclusions: Our results highlight the importance of a synergistic effect, i.e. the positive influence of grazers on viral activities in sustaining (directly and indirectly) bacterial production and affecting composition, in both oligotrophic and mesotrophic lakes.

Keywords: Lakes microcosm, spring-summer variations, bacterial production, viral production, bacterial community structure, grazers
\end{abstract}

\section{Background}

The heterotrophic bacterial community is the most important biological compartment involved in the transformation and mineralization of the organic matter in aquatic systems. It also constitutes a key source of prey for higher trophic levels, i.e. primarily flagellates, but

\footnotetext{
* Correspondence: jacquet@thonon.inra.fr

INRA, UMR CARRTEL, Station d'Hydrobiologie Lacustre, BioFEEL Group, 74203 Thonon-les-Bains cedex, France
}

also ciliates and the metazooplankton [1,2]. Our conceptual understanding of the role of heterotrophic bacteria in pelagic systems and in global biochemical cycles is closely linked to our understanding of how their growth rate, abundance, distribution and diversity are controlled [3-5].

Different biotic and abiotic factors have been identified as players acting on the activity and composition of the bacterial community, and resources (organic matter

\section{Biomed Central}


and nutrients) are considered one of the main factors controlling this community $[2,6]$. However, the roles of bacterivory and viral lysis are not insignificant, and may also strongly affect bacterial abundance, activity and structure. Both heterotrophic nanoflagellate (HNF) grazing and viral lysis are known to be variable causes of bacterial mortality, and can be responsible for 10 to $60 \%$ of daily bacterial loss in lacustrine systems [e.g. [7]]. In addition, both processes can impact the size distribution of bacterial communities through 'size-selective mortality' for flagellates $[8,9]$ and 'host-specificity' for viruses [10]. Moreover, viruses can act indirectly on bacterial structure throughout the release of cell debris during lysis activity (enriching the pool of dissolved and particulate organic matter (DOM and POM) and inorganic nutrients) enhancing in fine growth and production of some bacterial groups [11,12]. Indeed, whether cells are grazed or lysed can have different ecological and biogeochemical consequences, as the implications for the matter and energy flow through the microbial web will be very different $[13,14]$. Typically, high rates of viral cell lysis may generate a recycling of nutrients and organic matter at the base of the food web and therefore, less carbon and nutrients may reach higher trophic levels, a process referred to as the viral shunt $[13,14]$. In contrast, if bacteria are grazed by flagellates, nutrients and energy can reach higher trophic levels via the connection between the microbial loop and the classical food chain [15]. Thus, these processes can significantly influence the production of dissolved organic carbon and the recycling of nutrients $[14,16]$ and can impact/modify not only bacterial diversity $[9,17]$ but also the relationship between diversity and ecosystem functioning [18].

A few studies have investigated the individual effects of flagellates or viruses on bacterial communities in terms of abundance, production and diversity (e.g. $[7,10,19,20])$. However, their combined effects on bacteria, and the comparison between individual and combined effects are still limited [18,21,22]. According to these studies, both viral lysis and protistan bacterivory may act additively to reduce bacterial production and sustain diversity, which could explain the less pronounced blooming species in heterotrophic bacterioplankton than in phytoplankton [22]. However, the opposite effect has also been reported [23]. Moreover, comparisons of the combined effects of viruses and flagellates on the bacterial community according to the trophic status of aquatic systems are scarce and until now, no information has been made available for lacustrine systems. To the best of our knowledge, Zhang et al. [22] are the only authors who have investigated these effects taking into account a trophic range within a coastal ecosystem, and the same trend was highlighted [22]. According to these authors, a shift of predator control mechanisms from flagellates in oligotrophic systems to viruses in eutrophic systems could explain the results.

In this study, we collected samples from two perialpine lakes (Annecy and Bourget) with substantial differences in their trophic state (oligo- $v s$. mesotrophic, respectively) and we developed treatments with either individual or combined predators of the bacterial community using a fractionation approach (i.e. a physical separation of virus-bacteria and the small eukaryotes). Our main goal was to examine the separated and combined effect of viruses, grazers and small autotrophs $(<$ $5 \mu \mathrm{m})$ on the bacterial abundance, production and structure, and to compare it in different environmental conditions. Since the importance of both predators (flagellates and viruses) as potential controlling forces of the bacterial community may display seasonal variations in these lakes $[7,8,24]$, this study was carried out at two contrasting periods (early-spring vs. summer), characterized by substantial differences in both the dynamics and structure of microbial communities and environmental conditions $[8,25]$.

Our main findings are that both viral lysis and flagellated bacterivory act additively to sustain bacterial production, probably through a cascading effect from grazer-mediated resource enrichment, whereas their effects on the bacterial community structure remain more subtle. On the whole, the combined effects of viruses and flagellates showed the same trend in both lakes Annecy and Bourget.

\section{Results}

Initial conditions

\section{In situ characteristics of the study sites}

Lake Bourget is an elongated and north-south oriented lake situated in the western edge of the Alps (length 18 $\mathrm{km}$; width $3.5 \mathrm{~km}$; area $44 \mathrm{~km}^{2}$; volume $3.5 \times 10^{9} \mathrm{~m}^{3}$; altitude $231 \mathrm{~m}$; maximum depth $147 \mathrm{~m}$; mean depth 80 $\mathrm{m}$; residence time 8.5 years). Lake Annecy is located in the eastern part of France, at a distance of approx. 50 $\mathrm{km}$ from the former, (length $14.6 \mathrm{~km}$; width $3.2 \mathrm{~km}$; area $28 \mathrm{~km}^{2}$; volume $1.2 \times 10^{9} \mathrm{~m}^{3}$; altitude $447 \mathrm{~m}$; maximum depth of $65 \mathrm{~m}$; mean depth $41 \mathrm{~m}$; residence time 3.8 years). From the end of March to mid-July (i.e. periods during which experiments were conducted), in situ temperatures of the two study sites varied between $6.2^{\circ}$ $\mathrm{C}$ and $20.4^{\circ} \mathrm{C}$, while the dissolved oxygen varied more modestly, between 9.7 and $11.7 \mathrm{mg} \mathrm{l}^{-1}$ (Table 1). Differences in the concentration of nutrients $\left(\mathrm{NO}_{3}, \mathrm{NH}_{4}\right.$ and Ptot) between Lake Annecy and Lake Bourget were principally recorded during the early spring experiments (LA1 and LB1, respectively), with values twice to threetimes higher in Lake Bourget (LB1) than in Lake Annecy (LA1) (Table 1). Chl $a$ concentration was relatively low 
Table 1 Physicochemical and biological characteristics of the sampling sites ( $2 \mathrm{~m}$ depth)

\begin{tabular}{|c|c|c|c|c|c|}
\hline Parameters & & LA1 & LA2 & LB1 & LB2 \\
\hline $\begin{array}{l}\text { Sampling } \\
\text { date }\end{array}$ & & $\begin{array}{c}26 / 03 / \\
2007\end{array}$ & $\begin{array}{l}10 / 07 / \\
2007\end{array}$ & $\begin{array}{l}02 / 04 / \\
2007\end{array}$ & $\begin{array}{l}17 / 07 / \\
2007\end{array}$ \\
\hline Temperature & ${ }^{\circ} \mathrm{C}$ & 6.2 & 19.6 & 7.5 & 20.4 \\
\hline DO & $\mathrm{mg} \mathrm{I}^{-1}$ & 10.5 & 9.7 & 11.7 & 10 \\
\hline TOC & $\mathrm{mg}^{-1}$ & 1.7 & 2.2 & 2.1 & 2.5 \\
\hline $\mathrm{NO}_{3}$ & $\left.m g\right|^{-1}$ & 0.2 & 0.1 & 0.5 & 0.2 \\
\hline $\mathrm{NH}_{4}$ & $\mu \mathrm{gl}^{-1}$ & 2.0 & 1.0 & 6.0 & 4.0 \\
\hline $\mathrm{PO}_{4}$ & $\mu \mathrm{g} \mathrm{I}^{-1}$ & 2.0 & 3.0 & 4.0 & 2.0 \\
\hline$P$ total & $\mu \mathrm{g} \mathrm{I}^{-1}$ & 7.0 & 6.0 & 21.0 & 6.0 \\
\hline Chla & $\left.\mu g\right|^{-1}$ & 0.7 & 2.7 & 1.2 & 0.7 \\
\hline Cyanobacteria & $\begin{array}{c}10^{4} \text { cell } \\
\mathrm{ml}^{-1}\end{array}$ & $9.0 \pm 0.5$ & $15.0 \pm 1.1$ & $2.0 \pm 0.1$ & $12.0 \pm 0.8$ \\
\hline Het. Bacteria & $\begin{array}{c}10^{5} \text { cell } \\
\mathrm{ml}^{-1}\end{array}$ & $24.4 \pm 0.3$ & $12.3 \pm 0.4$ & $35.0 \pm 1.2$ & $25.2 \pm 2.0$ \\
\hline Viruses & $\begin{array}{c}10^{7} \text { part } \\
\mathrm{ml}^{-1}\end{array}$ & $3.7 \pm 0.1$ & $5.1 \pm 0.4$ & $8.3 \pm 0.3$ & $15.3 \pm 0.7$ \\
\hline HNF & $\begin{array}{c}10^{2} \text { cell } \\
\mathrm{ml}^{-1}\end{array}$ & $7.5 \pm 1.3$ & $6.9 \pm 0.6$ & $2.6 \pm 1.3$ & $3.9 \pm 1.5$ \\
\hline PNF & $\begin{array}{c}10^{2} \text { cell } \\
\mathrm{ml}^{-1}\end{array}$ & $4.9 \pm 1.3$ & $18.0 \pm 3.1$ & $1.4 \pm 0.2$ & $2.9 \pm 0.5$ \\
\hline
\end{tabular}

DO, dissolved oxygen; $\mathrm{Chl} a$, Chlorophyll $a$; TOC, total organic carbon; $\mathrm{NO}_{3}$, nitrate; $\mathrm{NH}_{4}$, ammonium; $\mathrm{P}$ total, total phosphorus; Het. Bacteria, heterotrophic bacteria; HNF, heterotrophic nanoflagellates; PNF, pigmented nanoflagellates. LA1, March sampling in Lake Annecy; LA2, July sampling in Lake Annecy; LB1, April sampling in Lake Bourget; LB2, July sampling in Lake Bourget. Values are means \pm standard deviation of results from triplicate measurements.

(i.e. $<2.8 \mu \mathrm{g} \mathrm{l}^{-1}$ ) for the four experiments (LA1, LA2, LB1 and LB2). The abundance of heterotrophic bacteria varied between 1.2 and $3.5 \times 10^{6} \mathrm{cell} \mathrm{ml}^{-1}$, viruses between 3.7 and $15 \times 10^{7}$ virus $\mathrm{ml}^{-1}$, heterotrophic nanoflagellates (HNF) between 2.6 and $7.6 \times 10^{2}$ cell $\mathrm{ml}^{-1}$, pigmented nanoflagellates (PNF) between 1.4 and $18 \times 10^{2}$ cell ml $^{-1}$, and picocyanobacteria between 2 and $15 \times 10^{4}$ cell ml$^{-1}$. These parameters were significantly different (ANOVA, $\mathrm{P}<0.05, \mathrm{n}=12$ ) between the four experiments (LA1, LA2, LB1 and LB2), indicating distinct biological characteristics at initial sampling. Seasonal difference in the picocyanobacterial abundance was monitored (ANOVA, $\mathrm{P}<0.05, \mathrm{n}=6$ ) in both lakes (Annecy vs. Bourget), with values 1.6- to two-times higher in summer (LA2 and LB2) than in early spring (LA1 and LB1). HNF and PNF abundances were significantly higher in Lake Annecy than in Lake Bourget (ANOVA, $\mathrm{P}<0.05, \mathrm{n}=12$, Table 1 ). In contrast, viral abundances were always lower in the oligotrophic Lake Annecy.

\section{Conditions in experimental bottles - Effect of filtration}

The $<5-\mu \mathrm{m}$ prefiltration removed a relatively small fraction of both HNF and PNF (less than 20\%), whereas the $<1.6-\mu \mathrm{m}$ filtration removed, as expected, all of them
(Table 2). At the start of the experiments, in VF (Viruses+Bacteria+Flagellates) and VFA (Viruses+Bacteria+Flagellates+Autotrophs) treatments, HNF abundances varied between $2.5 \times 10^{2}$ cell ml$^{-1}(\mathrm{LB})$ and $6.5 \times$ $10^{2}$ cell ml ${ }^{-1}$ (LA), PNF between $1.1 \times 10^{2}$ cell ml $^{-1}$ (LB) and $14.4 \times 10^{2}$ cell ml $^{-1}$ (LA), and picocyanobacteria between $0.7 \times 10^{4}$ cell ml ${ }^{-1}$ (LB) and $11.2 \times 10^{4}$ cell ml ${ }^{-1}$ (LA) corresponding to 52 to $72 \%$ of in situ abundances. Comparatively, a small fraction of the picocyanobacterial community passed through the $<1.6-\mu \mathrm{m}$ filter and only 0.1 and $0.8 \times 10^{4}$ cell ml ${ }^{-1}$ were recorded in treatment $\mathrm{V}$ (only bacteria and viruses), i.e. 1 to $5 \%$ of in situ abundance (Tables 1 and 2). In contrast, filtration through $1.6 \mu \mathrm{m}$ resulted in a small loss of bacterial and viral abundances (less than $14 \%$ and $20 \%$, respectively) whereas after 5 - $\mu \mathrm{m}$ filtration, loss never exceeded $4 \%$ for heterotrophic bacteria and $13 \%$ for viruses. At the beginning of the incubation, heterotrophic bacteria and viral abundances, in the four treatments of all experiments varied between $9.4 \times 10^{5}$ and $33.5 \times 10^{5}$ cell ml$^{-1}$ and between $2.9 \times 10^{7}$ and $13.4 \times 10^{7}$ virus $\mathrm{ml}^{-1}$, respectively (Figure 1). Overall, we succeeded in obtaining incubations with strongly contrasting predator pressure (with or without) and, with negligible loss to the abundances of both bacteria and viruses, when compared to in situ conditions.

\section{Effect of treatments on viral abundance and production}

Viral abundance only varied by a small degree (between $2.9 \times 10^{7}$ and $4.6 \times 10^{7}$ virus $\mathrm{ml}^{-1}$ ) in Lake Annecy, while it varied greatly in Lake Bourget particularly during the LB2 experiment (Figure 1). In both LA1 and LA2 experiments, the temporal trend of viral abundance revealed different patterns according to the treatment: viral abundance increased in VF and V treatment, while in the VFA treatment no significant evolution (ANOVA, $\mathrm{P}>0.05, \mathrm{n}=9$ ) was recorded (Figure 1). In Lake Bourget, viral abundance increased during the four days of incubation in all treatments, except in treatment $\mathrm{V}$ of the LB1 experiment. At the end of incubation, the increase in viral abundance in VF and VFA was significantly higher than in treatment $\mathrm{V}$ (ANOVA, $\mathrm{P}<0.01, \mathrm{n}$ = 9) in LA1 $(+39 \%$ and $+16 \%$, respectively), LB1 $(+34 \%$ and $+27 \%$, respectively) and LB2 $(+47 \%$ and $+61 \%$, respectively) (Figure 2D). However, the opposite was true for LA2 $(-6 \%$, ANOVA, $\mathrm{P}<0.05, \mathrm{n}=9)$. The stimulation of viral abundance was 3 -fold higher in Lake Bourget (average $+29 \%$ ) than in Lake Annecy (average $+8 \%)(\mathrm{t}$ test, $\mathrm{n}=24, \mathrm{P}<0.001$ ) and significantly different between seasons for each lake ( $t$ test, $n=12$, $\mathrm{p}<0.01$ ).

Similarly to viral abundance, viral production increased without exception from the beginning to the end of the experiments, particularly in VFA and VF 
Table 2 Picocyanobacteria (Synechococcus spp), pigmented and heterotrophic nanoflagellates (PNF and HNF) abundances at the beginning $\left(t_{0}\right)$ and at the end $\left(t_{\text {final }}\right)$ of each incubation in the different experiments

\begin{tabular}{|c|c|c|c|c|c|c|}
\hline Experiments and treatments & \multicolumn{6}{|c|}{ Abundance of: } \\
\hline & \multicolumn{2}{|c|}{ Picocyanobacteria $\left(10^{4}\right.$ cell $\left.\mathrm{ml}^{-1}\right)$} & \multicolumn{2}{|c|}{ PNF $\left(10^{2}\right.$ cell $\left.\mathrm{ml}^{-1}\right)$} & \multicolumn{2}{|c|}{ HNF $\left(10^{2}\right.$ cell $\left.\mathrm{ml}^{-1}\right)$} \\
\hline & $t_{0}$ & $t_{\text {final }}$ & $t_{0}$ & $t_{\text {final }}$ & $t_{0}$ & $t_{\text {final }}$ \\
\hline \multicolumn{7}{|l|}{ LA1 } \\
\hline V & $0.1 \pm 0.0$ & $0.3 \pm 0.0$ & $0.0 \pm 0.0$ & $0.0 \pm 0.0$ & $0.0 \pm 0.0$ & $0.0 \pm 0.0$ \\
\hline VFA & $6.5 \pm 0.1$ & $7.5 \pm 0.1$ & $4.5 \pm 1.3$ & $4.8 \pm 0.5$ & $6.2 \pm 1.3$ & $8.1 \pm 1.4$ \\
\hline VF & $5.5 \pm 0.1$ & $2.4 \pm 0.2$ & $4.2 \pm 0.2$ & $6.6 \pm 0.4$ & $6.5 \pm 0.9$ & $8.0 \pm 2.6$ \\
\hline \multicolumn{7}{|l|}{ LA2 } \\
\hline V & $0.8 \pm 0.4$ & $0.3 \pm 0.2$ & $0.0 \pm 0.0$ & $0.0 \pm 0.0$ & $0.0 \pm 0.0$ & $0.0 \pm 0.0$ \\
\hline VFA & $10.2 \pm 0.1$ & $15.8 \pm 0.1$ & $14.4 \pm 0.6$ & $28.5 \pm 1.3$ & $5.6 \pm 0.2$ & $11.1 \pm 0.8$ \\
\hline VF & $11.2 \pm 0.4$ & $6.3 \pm 0.3$ & $14.0 \pm 0.4$ & $19.1 \pm 0.1$ & $5.4 \pm 0.3$ & $13.5 \pm 0.8$ \\
\hline \multicolumn{7}{|l|}{ LB1 } \\
\hline V & $0.0 \pm 0.0$ & $0.0 \pm 0.0$ & $0.0 \pm 0.0$ & $0.0 \pm 0.0$ & $0.0 \pm 0.0$ & $0.0 \pm 0.0$ \\
\hline VFA & $0.8 \pm 0.0$ & $1.5 \pm 0.1$ & $1.3 \pm 0.5$ & $8.7 \pm 0.5$ & $2.5 \pm 0.5$ & $12.0 \pm 1.7$ \\
\hline VF & $0.7 \pm 0.2$ & $0.4 \pm 0.3$ & $1.1 \pm 0.7$ & $6.5 \pm 0.2$ & $2.9 \pm 0.6$ & $12.4 \pm 0.2$ \\
\hline \multicolumn{7}{|l|}{ LB2 } \\
\hline V & $0.3 \pm 0.0$ & $0.5 \pm 0.1$ & $0.0 \pm 0.0$ & $0.0 \pm 0.0$ & $0.0 \pm 0.0$ & $0.0 \pm 0.0$ \\
\hline VFA & $7.3 \pm 0.1$ & $16.6 \pm 2.1$ & $2.5 \pm 2.8$ & $7.5 \pm 8.9$ & $3.6 \pm 4.1$ & $20.7 \pm 11.7$ \\
\hline VF & $7.1 \pm 0.7$ & $3.1 \pm 0.2$ & $3.1 \pm 1.5$ & $12.5 \pm 0.9$ & $3.9 \pm 4.0$ & $13.8 \pm 9.0$ \\
\hline
\end{tabular}

V, Viruses+Bacteria treatments; VFA, Viruses+Bacteria+Flagellates+Autotrophs treatments; VF, Viruses+Bacteria+Flagellates treatments. LA1, LA2, LB1, LB2: abbreviations as in Table 1.

treatments whatever the lake (ANOVA, $\mathrm{P}<0.05, \mathrm{n}=9$ ). Viral production varied between a minimum of $3.2 \times$ $10^{5}$ virus $\mathrm{ml}^{-1} \mathrm{~h}^{-1}$ (LA2) and a maximum of $4.7 \times 10^{6}$ virus $\mathrm{ml}^{-1} \mathrm{~h}^{-1}$ (LB2) (Figure 3 ), which corresponded to $3.5 \times 10^{5}$ and $47.4 \times 10^{5}$ cells lysed $\mathrm{ml}^{-1} \mathrm{~d}^{-1}$, respectively (Table 3 ). Viral production in VFA and VF were, in most cases, significantly different (ANOVA, $\mathrm{P}<0.001, \mathrm{n}$ $=18$ ), over the course of the incubation, being on average $21 \%$ higher (range $7-53 \%$ ) than in $\mathrm{V}$ treatments in both lakes (Figure 2E). Stimulation of viral production seemed to be significantly higher ( $\mathrm{t}$ test, $\mathrm{P}<0.0001, \mathrm{n}=$ 24 ) in Lake Bourget (average $+30 \%$ ) than in Lake Annecy (average $+11 \%$ ), while no significant seasonal differences ( $\mathrm{t}$ test, $\mathrm{P}>0.05, \mathrm{n}=12$ ) were recorded for either lake.

\section{Effects of treatments on bacterial abundance, production and mortality}

Bacterial abundance increased throughout the experiments, particularly during the LB2 experiment (Figure 1). Concentrations were significantly higher in VFA and $\mathrm{VF}$ than in treatment $\mathrm{V}$ (ANOVA, $\mathrm{P}<0.05, \mathrm{n}=18$ ). Concentrations in VFA and VF were in most cases similar in Lake Annecy, when compared to each other (ANOVA, $\mathrm{P}>0.05, \mathrm{n}=18$ ), in contrast to the significant differences observed in the samples issued from Lake Bourget, with higher bacterial abundance in treatment VFA than VF. At the end of the incubation, the increase in bacterial abundance (comparison of treatments $\mathrm{V}$ and both VF and VFA between day 0 and day 4) in treatment VFA was significantly higher than in treatment $\mathrm{V}$ (ANOVA, $\mathrm{P}<0.01, \mathrm{n}=9$ ) (Figure 2A). In the four experiments, bacterial abundance was significantly higher (by up to $9 \%$ to $53 \%$ ) (t test, $\mathrm{P}<0.05$ ) in treatment VFA than in V. In the VF treatment, bacterial abundance was significantly higher (t test, $\mathrm{P}<0.05$ ) in LA2 (up to 35\%), LB1 (up to 30\%) and LB2 (up to 19\%) than in treatment $\mathrm{V}$. No significant difference was observed in LA1 ( $t$ test, $\mathrm{P}>0.8$ ). Stimulation of bacterial abundance was significantly different between lakes $(\mathrm{t}$ test, $\mathrm{P}<0.001, \mathrm{n}=24)(+38 \%$ in Lake Bourget and $+14 \%$ in Lake Annecy) and between seasons with highest values measured in summer $(+59 \%$ in Lake Bourget and $+26 \%$ in Lake Annecy).

During the incubation period, bacterial production fluctuated between 0.5 and $0.9 \mu \mathrm{gC}^{-1} \mathrm{~h}^{-1}$ in LA1, 0.8 and $2.3 \mu \mathrm{gC}^{-1} \mathrm{~h}^{-1}$ in LA2, 1.2 and $3.1 \mu g \mathrm{~g} \mathrm{l}^{-1} \mathrm{~h}^{-1}$ in LB1 and between 3.2 and $7.8 \mu \mathrm{gC}^{-1} \mathrm{~h}^{-1}$ in LB2 (Figure 3). Following bacterial abundance evolution, a significant increase in the bacterial production (ANOVA, P > 0.05, $\mathrm{n}=27$ ) was also recorded throughout the period of incubation. For both lakes, bacterial production was often higher in treatment $\mathrm{V}$ than in both VFA and VF during the early spring experiments (LA1 and LB1). After $96 \mathrm{~h}$ of incubation, the stimulation of bacterial production (comparison of variation of the viruses treatment $(\mathrm{V})$ and the grazers treatments (VFA and VF)) was observed in all experiments and averaged $27 \%$ in 

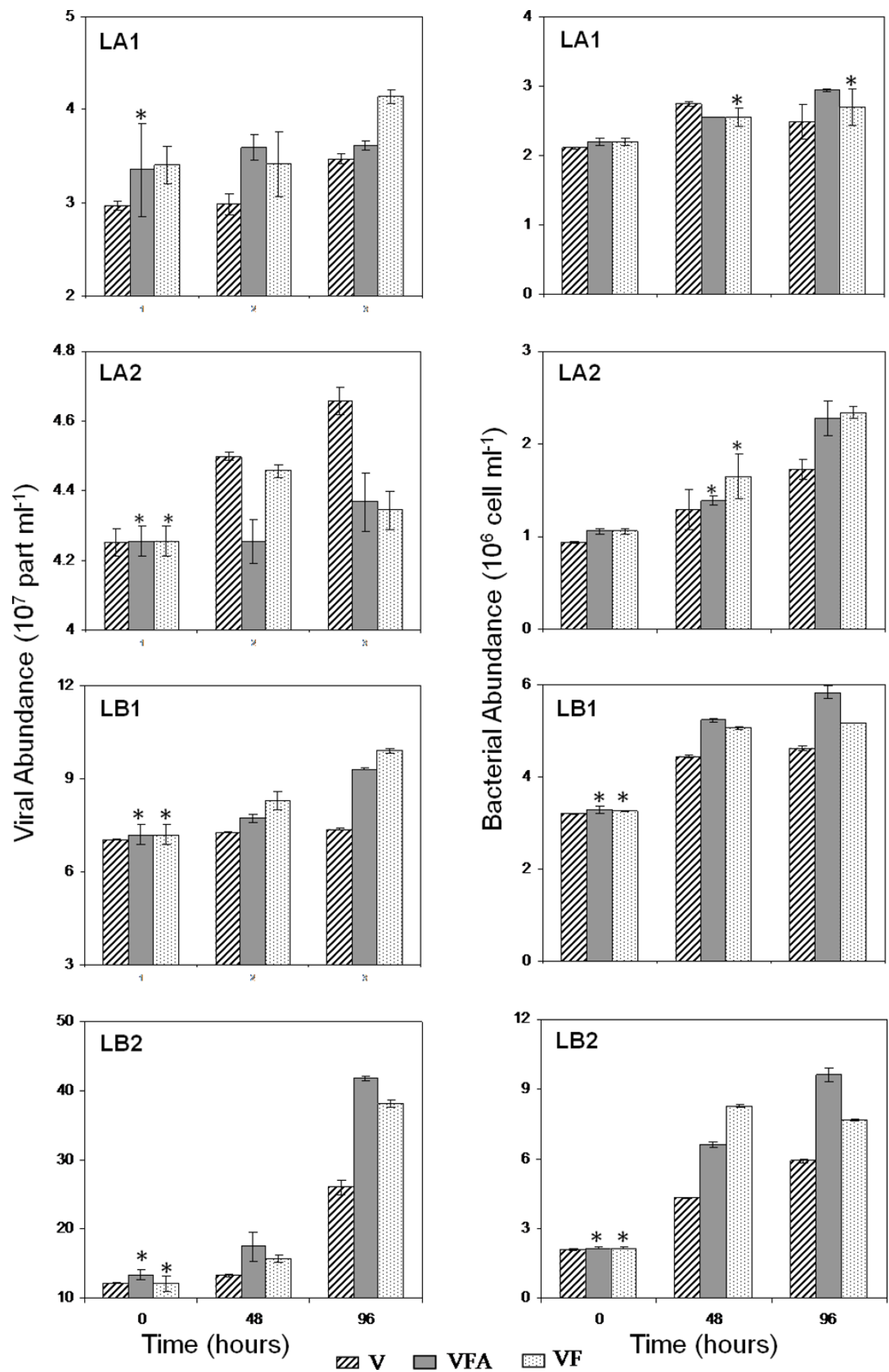

Figure 1 Time-course of viral abundance $\left(10^{7}\right.$ virus $\left.\mathrm{ml}^{-1}\right)$ and bacterial abundance $\left(10^{6}\right.$ cell $\left.\mathrm{ml}^{-1}\right)$ in the four experiments during the incubation period. Values are given as mean \pm standard deviation of triplicate incubations. Asterisks indicate sampling time point for which the $V F A$ and $V F$ treatments were not significantly different from the $V$ treatment (ANOVA, $P>0.05, n=9$ ). Note that the panels have different scales. LA1, LA2, LB1, LB2: abbreviations as in Table 1. 


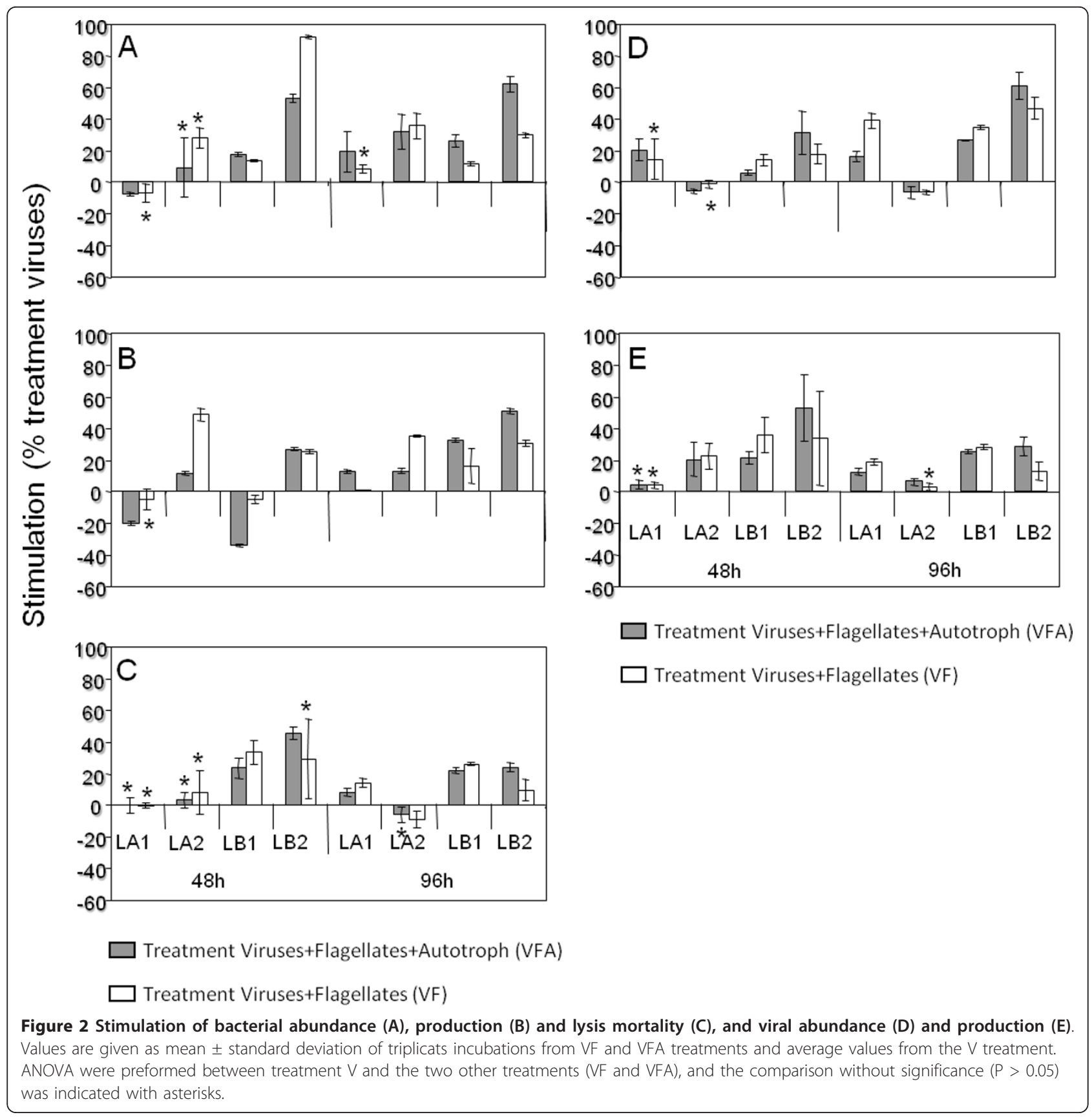

treatment VFA and $20.8 \%$ in treatment VF when compared to $\mathrm{V}$ (Figure 2B). The highest stimulation was observed in VFA during the LB2 experiment (51\%). Overall, the bacterial production was significantly different (ANOVA, $\mathrm{P}<0.001, \mathrm{n}=27$ ) between the three treatments for the four experiments, with the highest values observed in most cases in VFA and VF (Figures 2 and 3 ). In contrast to the bacterial abundance, a significant difference in the stimulation of bacterial production was only noted between seasons ( $\mathrm{t}$ test, $\mathrm{P}<0.001, \mathrm{n}=$ 12 ), with the highest values for summer experiments
$(+33.5 \%$ and $+37.5 \%$ for Lake Bourget and Lake Annecy, respectively).

Bacterial growth rate fluctuated between 0.1 and 0.7 $\mathrm{d}^{-1}$ after either $48 \mathrm{~h}$ or $96 \mathrm{~h}$ of incubation (Table 3 ), with the lowest values recorded during early spring experiments (LA1 and LB1). The presence of flagellates did not induce a reduction of bacterial abundance and the estimation of bacterial loss rates over time generally led to negative values, showing enhanced bacterial growth. In Lake Annecy, this positive impact on bacterial growth was only significant in the LA2 

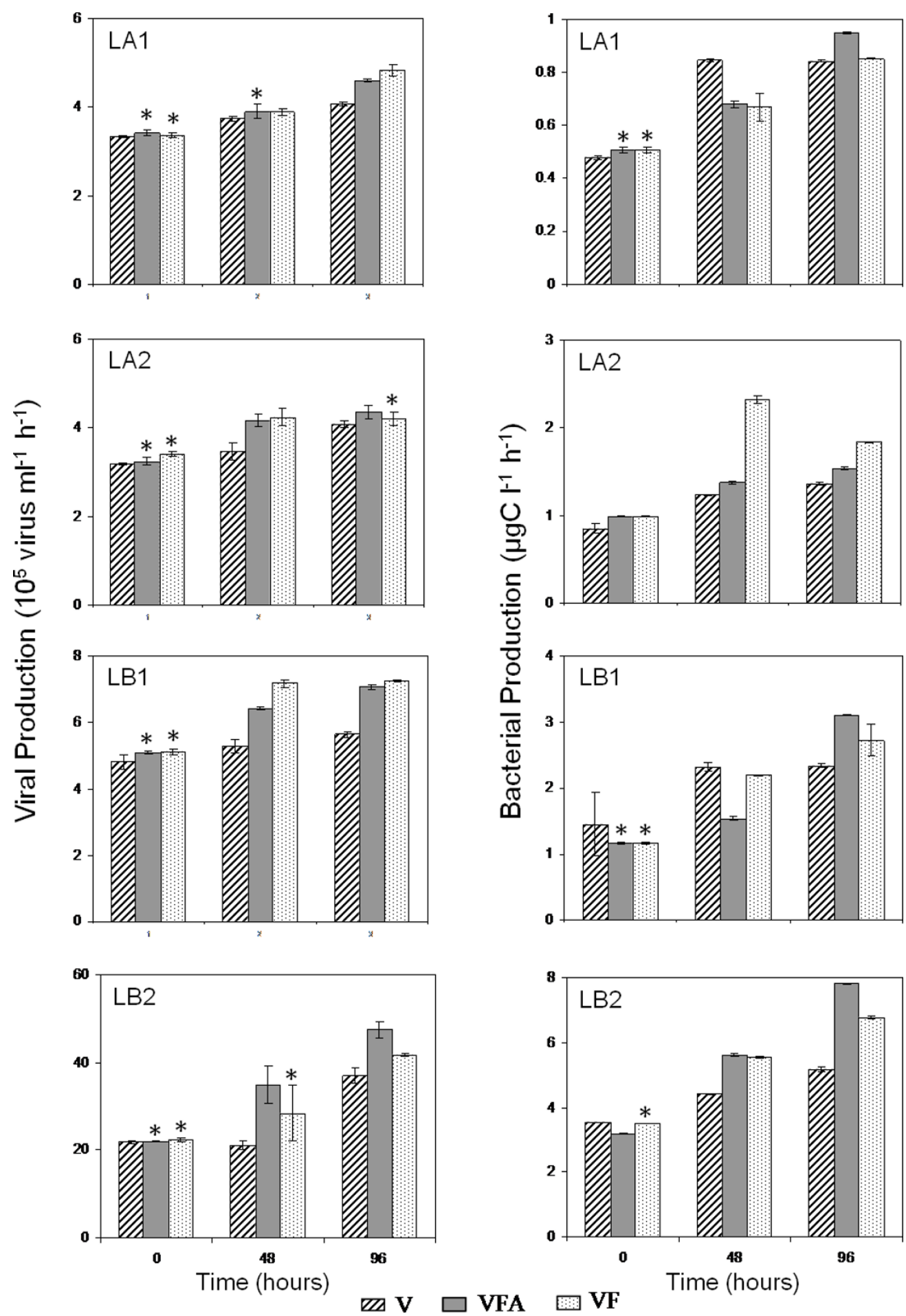

Figure 3 Time-course of viral production $\left(10^{5}\right.$ virus $\left.\mathrm{ml}^{-1} \mathrm{~h}^{-1}\right)$ and bacterial production $\left(\mu \mathrm{gC}^{-1} \mathrm{~h}^{-1}\right)$ in the four experiments during the incubation period. Values are given as mean \pm standard deviation of triplicate incubations. Asterisks indicate sampling time point for which VFA and VF treatments were not significantly different from the $V$ treatment $(P>0.05, n=9$, ANOVA). Note that the panels have different scales. LA1, LA2, LB1, LB2: abbreviations as in Table 1. 
Table 3 Bacterial growth rate (r), loss rate, virus-induced mortality and lysis activity rates after $48 \mathrm{~h}$ and $96 \mathrm{~h}$

\begin{tabular}{|c|c|c|c|c|c|c|c|c|c|c|}
\hline \multirow[t]{2}{*}{ Experiment/Treatment } & \multicolumn{2}{|c|}{ Growth rate $(r)\left(d^{-1}\right)$} & \multicolumn{4}{|c|}{ Loss rate of bacteria $\left(d^{-1}\right)$} & \multicolumn{2}{|c|}{ Lysis mortality $\left(d^{-1}\right)$} & \multicolumn{2}{|c|}{ Lysis rate activity $\left(10^{5}\right.$ cell $\mathrm{ml}^{-1} \mathrm{~d}^{-1}$} \\
\hline & $48 \mathrm{~h}$ & $96 \mathrm{~h}$ & $48 \mathrm{~h}$ & & $96 \mathrm{~h}$ & & $48 \mathrm{~h}$ & $96 \mathrm{~h}$ & $48 \mathrm{~h}$ & $96 \mathrm{~h}$ \\
\hline \multicolumn{11}{|l|}{ LA1 } \\
\hline VFA & $0.12 \pm 0.05$ & $0.14 \pm 0.01$ & $-0.03 \pm 0.09$ & & $-0.06 \pm 0.04$ & & $0.18 \pm 0.01$ & $0.21 \pm 0.01$ & $3.90 \pm 0.16$ & $4.60 \pm 0.04$ \\
\hline VF & $0.09 \pm 0.06$ & $0.10 \pm 0.06$ & $0.01 \pm 0.04$ & & $-0.02 \pm 0.01$ & & $0.18 \pm 0.01$ & $0.22 \pm 0.01$ & $3.80 \pm 0.07$ & $4.80 \pm 0.12$ \\
\hline V & $0.09 \pm 0.06$ & $0.08 \pm 0.05$ & & & & & $0.18 \pm 0.01$ & $0.19 \pm 0.01$ & $3.70 \pm 0.05$ & $4.10 \pm 0.04$ \\
\hline \multicolumn{11}{|l|}{ LA2 } \\
\hline VFA & $0.30 \pm 0.10$ & $0.37 \pm 0.03$ & $-0.02 \pm 0.15$ & & $-0.08 \pm 0.05$ & * & $0.39 \pm 0.01$ & $0.41 \pm 0.02$ & $4.20 \pm 0.14$ & $4.40 \pm 0.14$ \\
\hline VF & $0.36 \pm 0.36$ & $0.39 \pm 0.01$ & $-0.08 \pm 0.05$ & & $-0.09 \pm 0.05$ & * & $0.40 \pm 0.05$ & $0.40 \pm 0.02$ & $4.20 \pm 0.49$ & $4.20 \pm 0.14$ \\
\hline V & $0.28 \pm 0.03$ & $0.47 \pm 0.04$ & & & & & $0.37 \pm 0.02$ & $0.44 \pm 0.01$ & $3.50 \pm 0.20$ & $4.10 \pm 0.07$ \\
\hline \multicolumn{11}{|l|}{ LB1 } \\
\hline VFA & $0.27 \pm 0.02$ & $0.28 \pm 0.01$ & $-0.09 \pm 0.01$ & $* *$ & $-0.10 \pm 0.02$ & $* *$ & $0.20 \pm 0.01$ & $0.21 \pm 0.01$ & $6.40 \pm 0.05$ & $7.10 \pm 0.09$ \\
\hline VF & $0.27 \pm 0.00$ & $0.23 \pm 0.00$ & $-0.05 \pm 0.01$ & $* *$ & $-0.05 \pm 0.01$ & $* *$ & $0.22 \pm 0.01$ & $0.22 \pm 0.01$ & $7.20 \pm 0.11$ & $7.20 \pm 0.03$ \\
\hline V & $0.18 \pm 0.01$ & $0.18 \pm 0.01$ & & & & & $0.16 \pm 0.01$ & $0.18 \pm 0.01$ & $5.30 \pm 0.20$ & $5.60 \pm 0.08$ \\
\hline \multicolumn{11}{|l|}{ LB2 } \\
\hline VFA & $0.68 \pm 0.10$ & $0.73 \pm 0.01$ & $-0.21 \pm 0.01$ & $*$ & $-0.22 \pm 0.02$ & $* *$ & $1.62 \pm 0.19$ & $2.20 \pm 0.08$ & $34.9 \pm 4.30$ & $47.4 \pm 1.83$ \\
\hline VF & $0.65 \pm 0.02$ & $0.62 \pm 0.01$ & $-0.18 \pm 0.12$ & $*$ & $-0.11 \pm 0.01$ & $* *$ & $1.32 \pm 0.31$ & $1.94 \pm 0.03$ & $28.4 \pm 6.40$ & $41.7 \pm 0.26$ \\
\hline V & $0.47 \pm 0.10$ & $0.51 \pm 0.01$ & & & & & $1.01 \pm 0.04$ & $1.77 \pm 0.09$ & $21.1 \pm 0.96$ & $36.8 \pm 1.75$ \\
\hline
\end{tabular}

The significant difference between bacterial growth rate in $\mathrm{V}$ treatment and VFA/VF treatments was tested using ANOVA. ${ }^{*}, \mathrm{P}<0.05 ;{ }^{* *}, \mathrm{P}<0.001$.

experiment (ANOVA, $\mathrm{P}<0.05, \mathrm{n}=6$ ), and was observed in both VF $\left(-0.1 \mathrm{~d}^{-1}\right)$ and VFA $\left(-0.1 \mathrm{~d}^{-1}\right)$. In Lake Bourget, the two experiments (LB1 and LB2) showed the same effect on bacterial growth, with the highest values observed in VFA treatment $\left(-0.2 \mathrm{~d}^{-1}\right.$, ANOVA, $\mathrm{P}<0.001, \mathrm{n}=6$ ).

Bacterial mortality due to viral lysis activity was estimated to range between $0.2 \mathrm{~d}^{-1}$ and $2.2 \mathrm{~d}^{-1}$ (Table 3) with the highest values obtained during summer experiments (LA2 and LB2). Differences between V and VFA/ $\mathrm{VF}$ treatments indicated a significant increase in the lysis mortality rate after $48 \mathrm{~h}$ incubation in both LB1 $(+28 \%)$ and LB2 $(+43 \%)$ and this enhancement was maintained until the end (96 h) (Figure 2C). In LA1 and LA2, a significant difference between $\mathrm{V}$ and the other treatments was observed at the end of incubation, accompanied with an increase in lysis mortality rate in LA1 $(+11 \%)$, and a decrease in LA2 $(-7 \%)$.

\section{Effects of treatments on the bacterial community structure}

Figure 4 shows the PCR-DGGE patterns of the bacterial community structure at the start and end of incubation for the three treatments and the four experiments. Between 17 and 26 bands were found in treatment V, between 18 and 28 in VF and between 18 and 27 in VFA (Figure 4 and Table 4). The number of common bands found in the three treatments for each experiment represented between 24 and 49\% (average 40.5\%, Table 4). Between 0 and 3 bands (average 3.8\%) per experiment were specific to $\mathrm{V}$. Between 0 and 2 bands (average 2.3\%) and between 1 and 4 (average 6.5\%) bands were specific to VF and VFA, respectively (Table 4).

Among the eight sequenced bands, B2 (excised from the LA1 experiment) was present in all treatments. From this band, ten sequences out of 12 obtained were related to the genus Curvibacter (class of $\beta$-proteobacteria), the two other sequences corresponding to the genus Burkholderidia (class of $\beta$-proteobacteria) (Table $5)$. Three other sequenced bands were visible in all treatments but they increased significantly in intensity at the end of incubation (both B3 and B4 in $V_{\text {final }}$ of LA1, B8 in $\mathrm{VF}_{\text {final }}$ of LB2). These three excised bands were related to the phylum Actinobacteria (with B3 affiliated to the clade acI) (Figure 4 and Table 5). Finally, the three last bands chosen to be sequenced appeared ( $\mathrm{B} 5$ in $\mathrm{V}_{\text {final }}$ and $\mathrm{VF}_{\text {final }}$ of LA2) or disappeared (both B6 and B7 in $\mathrm{VFA}_{\text {final }}$ of LB1) at the end of incubation (Figure 4). These ones were all affiliated to the phylum Actinobacteria (as were $85 \%$ of the sequenced DGGE bands). Note that the excised band B1 (LA1 experiment), related to the phylum Cyanobacteria (Table 5), disappeared at the end of the incubation in both VF and V treatments.

Cluster analyses based on quantification of the band position and intensity (Figure 5) showed that, for each 


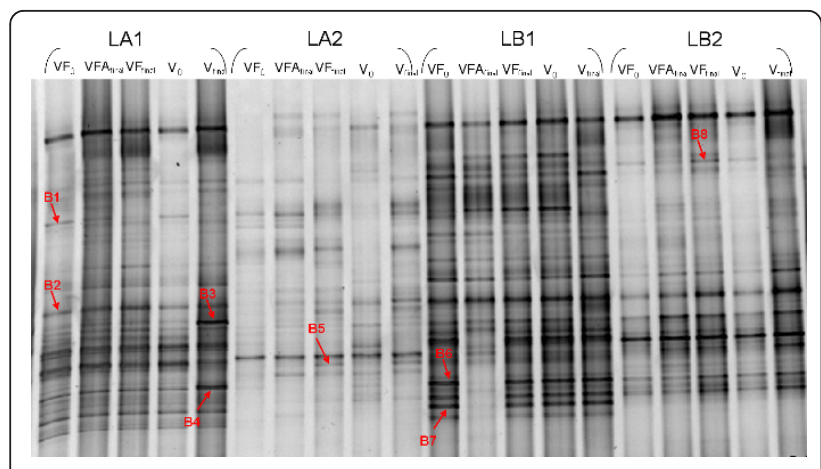

Figure 4 Bacterial community structure at the beginning (referred to as ' 0 ') and at the end ( $96 \mathrm{~h}$, referred as 'final') of the incubation, visualized by DGGE of PCR-amplified partial $16 S$ rRNA genes, and the position of the different bands excised and sequenced. (B1 to B8, see Table 5). $V_{0}$ and $V_{\text {Final, }}$ treatment Viruses+Bacteria at the beginning and the end of experiments; $V F_{0}$ and $V F_{\text {final, }}$ treatment Viruses+Bacteria+Flagellates at the beginning and the end of experiments, VFA final, treatment Viruses+Bacteria+Flagellates+Autotrophs at the end of experiments

lake, the bacterial community structure was clearly different according to the period (early spring/summer) (Figure 5). In lake Annecy, different responses could be observed following our manipulations: In spring, the effect of time (separation between $\mathrm{t} 0$ and $\mathrm{tf}$, whatever the planktonic size fraction) clearly affected the bacterial structure. In summer, the differences in the structure induced by the size fractionation were the strongest, and sample discrimination was clearly linked to the fractionation $(1.6 v s .5 \mu \mathrm{m})$. Similar patterns were obtained for Lake Bourget in summer. Finally, treatment VFA was highly divergent from V and VF (between $42 \%$ and 58\% of similarity) during the early spring experiment for Lake Bourget.

Table 4 Number and specificity of bacterial DGGE bands in the four experiments

\begin{tabular}{lcccc}
\hline & LA1 & LA2 & LB1 & LB2 \\
\hline Total Bands & 37 & 31 & 34 & 31 \\
Treatment Viruses & $22-23$ & $17-20$ & 26 & $17-25$ \\
Treatment Viruses + Flagellates & $25-28$ & $18-19$ & 27 & $19-23$ \\
Treatment Viruses + Flagellates & $25-28$ & 18 & $24-27$ & $19-27$ \\
+ Autotrophs & & & & \\
Bands common in all treatments & $47 \%$ & $42 \%$ & $49 \%$ & $24 \%$ \\
& $(16)$ & $(13)$ & $(18)$ & $(13)$ \\
Bands specific to: & & & & \\
Treatment Viruses & 0 & $3 \%(1)$ & $9 \%(3)$ & $3 \%(1)$ \\
Treatment Viruses + Flagellates & 0 & $6 \%(2)$ & $3 \%(1)$ & 0 \\
Treatment Viruses + Flagellates + & $11 \%$ & $6 \%(2)$ & $6 \%(2)$ & $3 \%(1)$ \\
Autotrophs & $(4)$ & & & \\
Two combined treatments (VFA + & $8 \%(3)$ & $6 \%(2)$ & $15 \%$ & $23 \%$ \\
VF) & & & $(5)$ & $(7)$ \\
\hline
\end{tabular}

\section{Discussion}

Experimental approach

In order to study the influence of both predation pressure and the autotrophic activity on bacterial community of Lakes Annecy and Bourget, we carried out a fractioning approach and performed incubation in either darkness or ambient light. The originality and strength of this study comes from the fact that such experiments were conducted (i) in two ecosystems with either oligotrophic or mesotrophic status and (ii) at two distinct periods of the year (i.e. early-spring and summer) where microbial planktonic dynamics and composition are likely to display clear differences $[8,24,25]$. Although the use of microcosms may introduce some bias into the development of microbial communities compared with those occurring naturally in the field (due to

Table 5 Phylogenetic information about the OTUs corresponding to the excised and sequenced DGGE

\section{bands}

\begin{tabular}{|c|c|c|c|}
\hline $\begin{array}{c}\text { Bands } \\
\mathrm{N}^{\circ}\end{array}$ & $\begin{array}{l}\text { Number of } \\
\text { sequenced } \\
\text { clones }\end{array}$ & OTUs & $\begin{array}{l}\text { Nearest uncultivated } \\
\text { species accession no }{ }^{\circ}, \% \\
\text { similarity }\end{array}$ \\
\hline B1 & 12 & $\begin{array}{c}\text { Phylum: } \\
\text { Picocyanobacteria } \\
\text { Synechococcus sp }\end{array}$ & AY224199, 98\% \\
\hline B2 & 10 & $\begin{array}{c}\text { Class: } \beta \text { - } \\
\text { proteobacteria } \\
\text { Genus: } \\
\text { Curvibacter }\end{array}$ & $\begin{array}{c}\text { EU703347, } 98 \\
\text { EU642369, } 99 \%\end{array}$ \\
\hline B2 & 1 & $\begin{array}{c}\text { Class: } \beta \text { - } \\
\text { proteobacteria } \\
\text { Genus: } \\
\text { Burkholderia }\end{array}$ & EU642141, 98\% \\
\hline B2 & 1 & $\begin{array}{c}\text { Class: } \beta \text { - } \\
\text { proteobacteria } \\
\text { Genus: } \\
\text { Burkholderia }\end{array}$ & $\begin{array}{l}\text { EU801155, 97\% } \\
\text { EU63973669, 96\% }\end{array}$ \\
\hline B3 & 9 & $\begin{array}{l}\text { Phylum: } \\
\text { Actinobacteria } \\
\text { Clade: acl }\end{array}$ & FJ916243, 99\% \\
\hline B4 & 11 & $\begin{array}{l}\text { Phylum: } \\
\text { Actinobacteria } \\
\text { Unidentified }\end{array}$ & FN668296, 99\% \\
\hline B5 & 10 & $\begin{array}{l}\text { Phylum: } \\
\text { Actinobacteria } \\
\text { Unidentified }\end{array}$ & FN668268, 100\% \\
\hline B5 & 1 & $\begin{array}{l}\text { Unclassified } \\
\text { bacteria }\end{array}$ & \\
\hline B6 & 12 & $\begin{array}{c}\text { Phylum: } \\
\text { Actinobacteria } \\
\text { Unidentified }\end{array}$ & FJ916291, 99\% \\
\hline B7 & 11 & $\begin{array}{l}\text { Phylum: } \\
\text { Actinobacteria } \\
\text { Unidentified }\end{array}$ & DQ316369, 99\% \\
\hline B8 & 8 & $\begin{array}{l}\text { Phylum: } \\
\text { Actinobacteria } \\
\text { Unidentified }\end{array}$ & AJ575506, 99\% \\
\hline B8 & 3 & $\begin{array}{l}\text { Unclassified } \\
\text { bacteria }\end{array}$ & \\
\hline
\end{tabular}




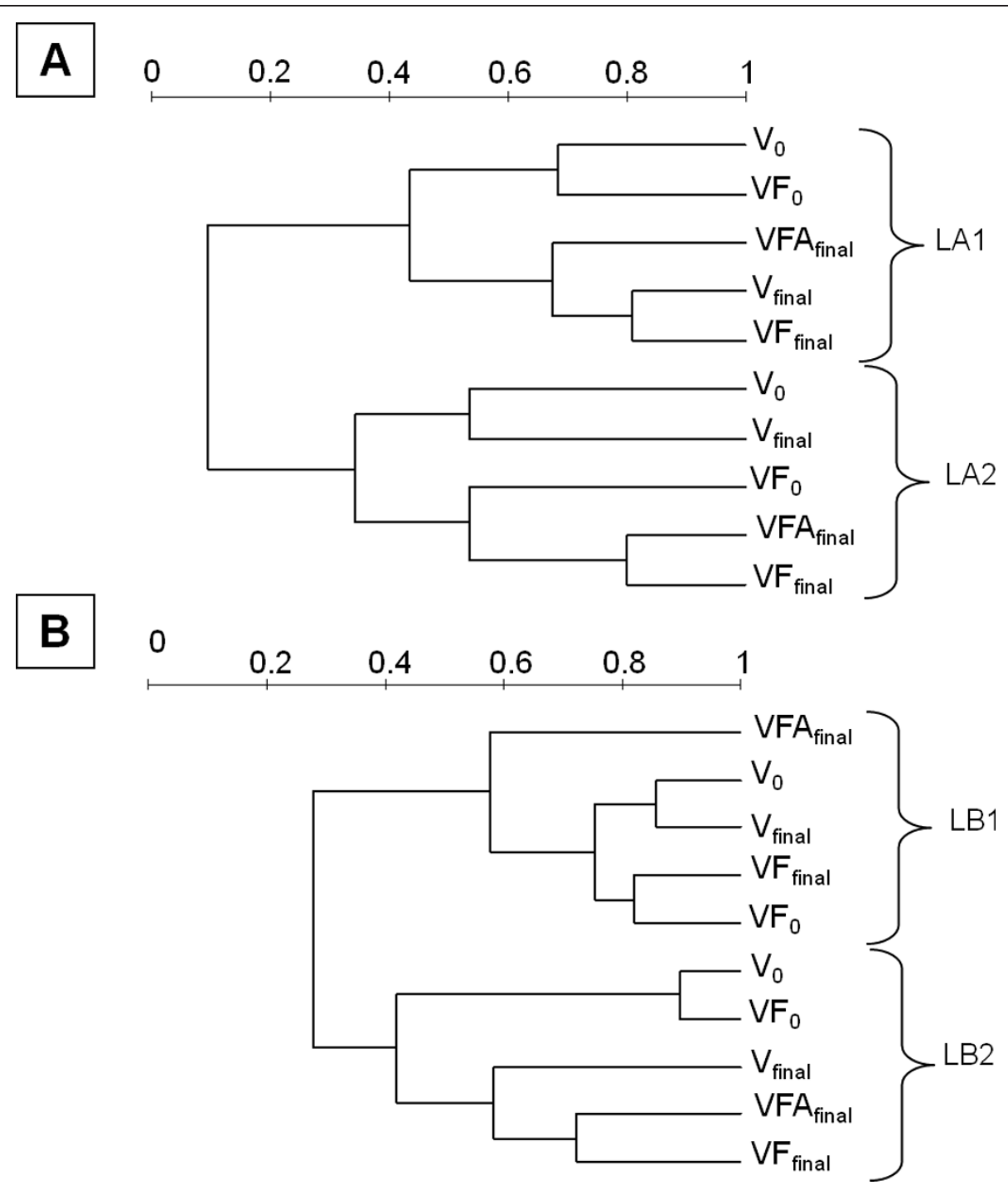

Figure 5 Cluster analysis of DGGE profiles based on band position and intensity. Scale bars indicated the Bray-Curtis similarity index in Lake Annecy (A) and Lake Bourget (B). $V_{0}$ and $V_{\text {Final, }}$, treatment Viruses+Bacteria at the beginning and the end of experiments; $V F_{0}$ and $\mathrm{VF}_{\text {final, }}$, treatment Viruses+Bacteria+Flagellates at the beginning and the end of experiments, VFA final, treatment Viruses+Bacteria+Flagellates + Autotrophs at the end of experiments.

confinement and handling effects), these experimental tools are still very useful for investigating how processes such as mortality factors induce temporal variation in bacterial dynamics, structure and activity [26]. Incubation time (4 days) coupled with the volume of microcosms $(2.5 \mathrm{~L})$ considered in this study have previously been used successfully in other experimental studies $[18,22]$. We assumed that our design was thus realistic enough compared to the generation time of microorganisms and aimed to obtain significant changes in bacterial and viral activity [27]. A comparison of virus and flagellate abundances at the onset of the experiments with in situ conditions and among treatments with different viral and flagellate effects was successful. However, the experimental protocol resulted in a reduction of HNF at the start of the experiment and we thus might have underestimated their influence. Clear effects of HNF were observed at the end of the experiment, when flagellate abundance was about twice as high as in situ (Tables 1 and 2).

\section{Grazing effect on viral activity}

According to the model of Miki and Yamamura [28], grazers should reduce the role of the viral loop. As viral production was higher in VF and VFA treatments than in $\mathrm{V}$ in most cases, particularly after $48 \mathrm{~h}$ incubation, our results instead suggested a stimulation of viral activity in the presence of grazers. Such a stimulation of viral 
production by the presence of small eukaryotes (grazers) was observed in all experiments for the two lakes. These results corroborate the findings of Jacquet et al. [27] who observed a clear and positive relationship between flagellate concentration and VIBM (virus-induced bacterial mortality) in Lake Bourget $(r=0.99, \mathrm{P}<0.05)$ at three different periods of the year (winter, spring and summer), suggesting a synergistic cooperation between grazer and virus activity. Our new results extend the occurrence of this process at other periods of the year and in the oligotrophic Lake Annecy. Similar beneficial effects of protozoan grazing on viruses have been reported in various lacustrine systems with different trophic statuses $[21,23,26]$. This means that the trophic status cannot be 'used' as an environmental factor to change the balance between positive and negative effects of flagellates on viruses [29], and it is likely that there are probably different processes involved in enhancing viral activities in response to grazing activity [21].

To the best of our knowledge, Šimek et al. [19] were first to suggest that protozoan grazing may influence and increase viral lysis. From that time, other studies reported such a synergistic effect in contrast to freshwater systems $[21,26,27]$. Nevertheless, an antagonistic interaction between these two compartments was also noted elsewhere [30,31]. Mechanisms by which HNF affect viral activity are still unclear and many hypotheses have been proposed to explain such a cooperative interaction (reviewed by Miki and Jacquet [29]). In brief, grazing activity could stimulate bacterial growth rates, by releasing organic and inorganic nutrients. Higher bacterial growth rates might be associated with enhanced receptor formation on cell surface which may result in a greater chance of phage attachment and in fine higher infection frequencies. Thus, grazer stimulation of viral proliferation could occur through cascading effects from grazer-mediated resource enrichment [23]. We observed, in this study, a strong stimulation of bacterial production in treatments with grazers which may corroborate this assumption in both lakes. A link between infection and host production has been reported previously (summarized in Weinbauer [11]) and, recently, experimental studies showed that viruses may preferentially lyse active cells $[18,32]$. Our results showed that autotrophic activity contributed to this stimulation, mainly in the early summer experiment (for both lakes), while heterotrophic flagellates were always involved in this positive feedback. A shift in the bacterial community structure could also contribute to the synergistic interaction observed in this study. According to Weinbauer et al. [33], grazing can favour species which are capable of rapid growth and resistant to grazing, which may stimulate viral infection. Our results also seemed to support this hypothesis since both high bacterial production and specific bands were only observed in treatments VF and VFA.

Stimulation of viral production was much more variable between lakes than between seasons and it was clearly higher in Lake Bourget. This suggests that environmental conditions encountered in the mesotrophic system might promote higher viral activity compared to more oligotrophic conditions. This hypothesis agrees with Lymer et al. [34] or Pradeep and Sime-Ngando [26] who observed, during a microcosm experiment, an enhancement of both viral abundance and FIC (frequency of infected cells) in P-enriched samples as a result of nutrient stimulation of bacterial growth, which in turn enhanced viral activity. However, it is noteworthy here that although phosphorus concentration was 2-fold higher in Lake Bourget than in Lake Annecy (Table 1), no significant difference was recorded in bacterial production between the two lakes ( $t$ test, $\mathrm{P}>$ 0.005). Some studies have suggested that nutrient availability may have an important influence on viral life strategies (e.g. $[35,36])$. As lysogenic infection is considered the most favourable method of bacterial infection in water characterized by low bacterial abundance and primary production, this may also explain the relatively weak stimulation of viral production observed in Lake Annecy compared to Lake Bourget [32].

In Lake Annecy, and in contrast to viral production, the effects of flagellate presence on viral abundance seemed to be highly variable between the two periods (LA1 vs. LA2). This variation revealed viral abundance stimulation in early-spring (LA1) and repression in summer (LA2), for both treatments (VFA and VF). This result could suggest a direct grazing of flagellates on viruses during summer. Virivory by flagellates has been previously reported $[37,38]$ and according to Domaizon et al. [39], all flagellates do not act similarly because of large differences between taxon-specifc ingestion rates. During our study, heterotrophic flagellates were mainly represented by Oikomonas ( 45 and $48 \%$ during LA1 and LA2, respectively). Also, the grazing impact of flagellates on viruses has always been reported to be relatively low, resulting in $<4 \%$ loss $[37,38]$. Hence, direct grazing of flagellates on viruses was unlikely to explain the repression of viral abundance in LA2. Other factors should be invoked [36] and would need further investigation.

\section{Effect of both flagellates and viruses on bacterial activity} Higher bacterial production in both VF and VFA treatments than $\mathrm{V}$ suggested that grazers and viruses acted additively to sustain (directly or indirectly) bacterial activity in Lake Annecy and Lake Bourget. Such bacterial growth and activity stimulation in the presence of grazers and viruses has been previously reported in the oligotrophic Sep reservoir, Massif Central, France 
$[23,26]$. However, the control and reduction of bacterial production by the two mortality agents have been observed in other aquatic systems $[18,21,22]$. Such variability in possible responses could be due to the initial bacterial community composition and environmental conditions.

The increase in bacterial production with the presence of both predators (flagellates and viruses) could be explained by the fact that grazing activity and viral lysis are likely to release inorganic and organic nutrients which may stimulate bacterial activity. Obviously, the absence of direct measurements of grazing rates of flagellates on heterotrophic bacteria communities, for instance using fluorescently labelled bacteria (FLB) [40], prevented us from drawing firm conclusions about the grazing pressure of HNF on bacteria and our results should be considered in light of that. However, it has been suggested that a minimal proportion of 1,000 heterotrophic bacteria for one heterotrophic flagellate is characteristic of microbial food webs in which flagellates preferentially consume bacteria $[39,41,42]$. The value for this ratio was higher than 1,000 in each treatment (VFA $v s$. VF) and for each experiment (early spring vs. summer). Indeed it varied between 1,632 and 3,866 bacteria per flagellate in Lake Annecy (mean value: 2,795), and between 2,619 and 8,857 in Lake Bourget (mean value: 5899), suggesting that heterotrophic bacteria were abundant enough to support the development of the heterotrophic flagellates that were present.

Seasonal variability in the stimulation of bacterial production seemed to be more important than the trophic status variability, with highest mean values recorded in summer $(+33.5 \%$ and $+37.5 \%$ in Lakes Bourget and Annecy, respectively), a period which corresponds to low total phosphorus conditions and high temperature in surface waters (Table 1). Thus, the input of nutrient resources by viral and grazing activities, under such summer conditions, is likely to stimulate the bacterial community much more than under the cold early-spring conditions (temperature $=6-7^{\circ} \mathrm{C}$ ). Moreover, Thomas et al. [32] observed that the abundance of HDNA (high nucleic acid containing bacteria) is lower in spring than in summer in Lake Bourget (less than $40 \%$ of the total bacterial abundance), and this group is considered to be more active in comparison to LDNA (low nucleic acid bacteria) $[43,44]$. This could also explain the low stimulation of bacterial production in early spring compared to that in summer.

For most experiments (LA1, LB1 and LB2), the stimulation of bacterial production, at the end of experiments, was much higher in VFA than in the VF treatment (Figure 4) which could be attributed to an increase in substrate availability and regenerated nutrients, resulting from grazing pressure of flagellates on both heterotrophic bacteria and autotrophic communities, in treatment VFA $[45,46]$. Nevertheless, the opposite situation was observed in Lake Annecy during the summer period (LA2 experiment) suggesting weaker competition by the bacterial community for nutrient resources in the presence of autotrophs, at this period. As a possible explanation, the abundance of autotrophs (represented mainly by picocyanobacteria and PNF) was indeed 2- to 4-fold higher in summer than in early spring while bacterial abundance was 2 -fold lower (Table 1).

\section{Impact of HNF on bacterial community structure}

We are aware that the DGGE fingerprinting method presents some bias and only reflects the microorganism populations that are present at relatively high concentrations. For example, while Muyzer et al. [47] claimed that the reported sensitivity of DGGE is $1 \%$ of the template DNA, Casamayor et al. [48] reported that the number of bands is related to the number of populations that account for more than $0.3-0.4 \%$ of the total cell counts. In addition, some other bias such as insufficient or preferential disruption of cells during the DNA extraction step, amplification bias (chimera and heteroduplex formation) and band co-migration in the DGGE gel can occur and consequently over- or underestimate the number of bands. However, such limitations are not specific to DGGE and may also be found in other molecular fingerprinting techniques [49]. Therefore, it must be kept in mind that only major changes in the bacterial community composition could be monitored using DGGE. That is exactly what we observed in this study as all sequenced bands belonged to Actinobacteria and Proteobacteria, known to be the most dominant phyla in lakes $[50,51]$. Thus our results have to be interpreted with caution because the structure of some "non-dominant" phyla, non-detectable with the DGGE technique, could have changed according to the treatments performed in this study.

We found that some bands were specific to each treatment suggesting that some bacterial phylotypes were able to develop and thwart the predation pressure. Such specificity has already been reported in other experimental studies $[18,21,22]$. Phylotypes, observed in both VFA and VF treatments, were likely to be resistant to both grazing and infection [21,22]. Nevertheless, the presence of phylotypes only in VF (not in VFA) might indicate sensitivity to the autotrophic activity as a result of a weak ability to compete for resources. Phylotypes only present when viruses were the exclusive mortality agents would probably not be able to deal with the combined pressure of grazing and viral lysis [21] or were strongly susceptible to grazing as already suggested by Zhang et al. [22]. Finally, the appearance of bands in both VF and VFA treatments could be due to 
phylotypes benefiting from the presence of predators, e. g., via the production of DOM or by the removal of competitors.

A few previous experimental studies have shown that viruses can influence the presence or absence of specific bacterial phylotypes but, typically, result in a reduction of the number of detected phylotypes [53,54]. In contrast, we observed during the summer period an increase in the apparent richness when viruses were the exclusive mortality agents (i.e. the number of detectable bands) giving support to the "killing the winner hypothesis". The stimulation of bacterial diversity in the presence of viruses was also reported in other lacustrine systems by Weinbauer et al. [21] and other experimental studies performed in coastal marine systems observed the same trend $[18,22]$. However, the relative stability of the apparent richness during early spring experiments, in treatment $\mathrm{V}$, highlighted the seasonal variability of virus effects on bacterial diversity. This high variable impact of viruses upon bacterial community structure, already reported by Hewson and Fuhrman [54], could suggest the influence of stochastic processes.

Since no decrease in the number of bands was observed in either treatment VF or VFA, our result could not support the hypothesis of Miki and Yamamura [28] according to whom grazing on infected cells "Kills the killer of the winner" and thus reduces bacterial species richness. In some cases, the combined effect of viruses and flagellates on bacterial fingerprint diversity was more consistent than the effect of viruses alone, suggesting that both predators acted additively to sustain apparent richness. According to Zhang et al. [22] the 'killing the winner' hypothesis is mediated by both predators and not just by one type of predator (viruses). Thus, all predators (viruses and flagellates) could act additively in controlling the winners of the competition for resources and caused an increase in detectable phylotypes. In addition, stimulation of bacterial production and related viral lysis also suggested input of nutrients and substrates from grazing and lysis activities which may decrease the competition pressure within bacterial community, thereby increasing the competitiveness of the minor phylotypes [23].

The effect of both predators on the bacterial diversity was not apparent in all experiments, suggesting more variability and complexity in the interactions between bacterial diversity, viruses and grazers than hitherto assumed. Diverse patterns between predators and bacterial diversity were reported in other studies $[18,19,55]$. Such variability could be explained by the change in the balance between bacterial production and protistan grazing [56] or to chaotic behaviour due to competition among predators for the same prey [28]. Overall, previous work performed in both Lakes Annecy and
Bourget, indicated that the strong complexity of the combined physico-chemical and biological parameters (with a larger effect of abiotic factors) is mainly responsible for the evolution of the bacterial community structure [57].

\section{Conclusion}

Many forms of interaction exist between the various components of the microbial loop including the viruses. Our results highlight that viruses and flagellated grazers are likely to act together, synergistically, on bacterial activity and community structure. Even at the community level, interactions between bacterioplankton, viruses and grazers are thus much more complex than hitherto assumed. More than ever, additional studies are needed to fully assess the factors responsible for the variability in the interactions between grazers, bacteria and viruses, especially in freshwater ecosystems, as well as their ecological significance for the microbial community structure/role and whole ecosystem functioning.

\section{Methods}

\section{Study sites and sampling}

Water samples were collected from the two largest natural lakes in France. For the purpose of this study, 40 litres of water samples were collected near the surface (i.e. $2 \mathrm{~m}$ ) using a water pump and large tubing on 26 March and 10 July 2007 in Lake Annecy (referred to later as LA1 and LA2, respectively) and on 02 April and 17 July 2007 in Lake Bourget (i.e. LB1 and LB2). In this way, for each period, samples were separated by only one week between the two lakes.

\section{Physicochemical variables}

Total organic carbon (TOC) and nutrient concentrations $\left(\mathrm{NH}_{4}, \mathrm{NO}_{3}, \mathrm{PO}_{4}\right.$, total phosphorus) were measured at each station and date, according to the standard French protocols AFNOR (details available at http://www.dijon. inra.fr/thonon/les_plateaux_techniques/le_laboratoire_de_physico_chimie). A conductivity-temperature-depth measuring device (CTD SEABIRD SAB 19 Seacat profiler) and a Chlorophyll fluorescence Fluoroprobe (BBE Moaldenke, Germany) were used to obtain vertical profiles of water temperature, conductivity, dissolved oxygen concentration and chlorophyll $a$ fluorescence.

\section{Size fractionation approach}

Immediately after sampling, samples were pre-filtered through a $60-\mu \mathrm{m}$ mesh screen, followed by pre-filtration through Nucleopore membranes $(<5-\mu \mathrm{m}$ pore size $)$ under low differential pressure $(<50 \mathrm{~mm} \mathrm{Hg})$ in order to exclude large eukaryotes. We could thus focus our attention on the small eukaryotes, autotrophic and heterotrophic prokaryotes and viruses. A third of the pre- 
filtered sample was then filtered through $1.6-\mu \mathrm{m}$ pore size to yield a total free-living bacteria and 'grazer-free' containing fraction, which was confirmed by detailed microscopic examination at the beginning and at the end of the experiments. The remaining pre-filtred sample was divided into two parts; one of them was kept in a black box (simulating darkness) to inhibit the autotrophic activity. Therefore, three combinations of treatments were performed: the treatment 'Viruses + Bacteria + heterotrophic Flagellates (grazers) + Autotrophs' (fraction $<5 \mu \mathrm{m}$, referred to as VFA); the treatment 'Viruses + Bacteria + Flagellates (grazers)' (fraction $<5 \mu \mathrm{m}$ put into a black box; VF) and finally the treatment 'Viruses + Bacteria', i.e. without the flagellates and the autotrophic community (fraction $<1.6 \mu \mathrm{m}$, referred as V).

Samples so transformed were divided into triplicates and poured into $2.5 \mathrm{~L}$ Nalgene transparent carboys, which had been previously cleaned with $1.2 \mathrm{~N} \mathrm{HCl}$ and rinsed three times with Milli-Q and filtered lake water. All the bottles were incubated in the lake at $2 \mathrm{~m}$ depth for four complete days. Subsamples were taken from each triplicate at day 0,2 and 4 to assess microbial abundances and activities, and at day 0 and 4 for the analysis of the bacterial community diversity.

\section{Flow cytometry (FCM) sample analysis}

We used a FACSCalibur flow cytometer (Becton Dickinson, Franklin Lakes, NJ, U.S.A.) equipped with an aircooled laser providing $15 \mathrm{~mW}$ at $488 \mathrm{~nm}$ with the standard filter set-up. Only a few hours after sampling (less than $4 \mathrm{~h}$ ), one millilitre of water was immediately analysed without adding any fixative or dye to analyse the picocyanobacterial community dynamics and also to check for the absence/presence of prokaryotic (e.g. Synechococcus) and eukaryotic autotrophic organisms in the $\mathrm{V}$ treatment. Such unfixed samples, kept in darkness in refrigerated boxes and at $4^{\circ} \mathrm{C}$ for a few hours before analysis, revealed no significant changes in cell counts while this was not true when using either formaldehyde or glutaraldehyde (not shown). Fluorescent microbeads (Molecular Probes Inc., Eugene, OR, U.S.A.) of 1- $\mu \mathrm{m}$ diameter were added to each sample as an internal standard. Another $1 \mathrm{ml}$ was fixed and used for bacterial and viral counts via FCM, according to the protocol described in Personnic et al. [25]. Briefly, viruses were fixed with glutaraldehyde $(0.5 \%$ final concentration, grade I, Merck) for $30 \mathrm{~min}$ in the dark, then diluted in $0.02 \mu \mathrm{m}$ filtered TE buffer $(0.1 \mathrm{mM}$ Tris-HCL and 1 mM EDTA, pH 8), and incubated with SYBR Green I (at a final $5 \times 10^{-5}$ dilution of the commercial stock solution; Molecular Probes), for $5 \mathrm{~min}$ at ambient temperature, followed by $10 \mathrm{~min}$ at $75^{\circ} \mathrm{C}$, and then another 5 min at room temperature, prior to FCM analysis.
Heterotrophic bacterial counts were performed on samples that had also been fixed with glutaraldehyde $(0.5 \%$ final concentration) for 30 minutes, but the samples were then diluted in $0.02 \mu \mathrm{m}$ filtered deep-lake water sample, and incubated with SYBR Green I $\left(10^{-4}\right.$ dilution of the commercial stock solution) for 15 min [25] Listmode files were analysed using Cytowin [58].

\section{Enumeration of flagellates}

$50 \mathrm{ml}$ sub-samples were fixed with glutaraldehyde (1\% final concentration), stained with primuline [59] and collected onto black polycarbonate membranes $(0.8-\mu \mathrm{m}$ pore size). For flagellates, slides were prepared within 24 $\mathrm{h}$ after sampling and were stored at $-25^{\circ} \mathrm{C}$ in darkness to minimise the loss of autofluorescence [60]. Slides were observed at a $1,250 \times$ magnification using an epifluorescence microscope (Nikon Eclipse TE200) under UV light for heterotrophic nanoflagellates and, under blue and green light for pigmented nanoflagellates.

\section{Bacterial production}

The incorporation of ${ }^{3} \mathrm{H}$-leucine was determined following the protocol of Kirchman [61]. For each sample, 5 sterile eppendorfs $(2 \mathrm{ml})$ received $1 \mathrm{ml}$ of sub-sample. Two samples were fixed with formaldehyde (1.6\% final conc.) to serve as controls. Eppendorfs were inoculated with known saturating ${ }^{3} \mathrm{H}$-Leu (80 nM final concentration, specific activity: $73 \mathrm{Ci}^{\mathrm{mmol}}{ }^{-1}$ ) and incubated in the dark for $2 \mathrm{~h}$. Protein synthesis was stopped by the addition of formaldehyde (1.6\% final concentration). Samples were then filtered through a $25-\mathrm{mm}$ diameter, $0.22-\mu \mathrm{m}$ pore size membrane (GTTP). The filters were then rinsed twice with $5 \mathrm{ml}$ of trichloroacetic acid (TCA, 5\% final concentration). The filters were placed in scintillation vials, allowed to dry and solubilised with $1 \mathrm{ml}$ of toluene. After adding $3 \mathrm{ml}$ of the scintillation cocktail (Hionic Fluor, Perkin Elmer), the radioactivity was counted with a Packard Tricarb Liquid Scintillation Analyser 1500. Bacterial production, calculated in pmoles $\mathrm{l}^{-1} \mathrm{~h}^{-1}$ of ${ }^{3} \mathrm{H}$-Leucine incorporated into protein, was converted in $\mu \mathrm{gC}^{-1} \mathrm{~h}^{-1}$ following Simon and Azam [62]: BP $\left(\mu \mathrm{gC} \mathrm{l}^{-1} \mathrm{~h}^{-1}\right)=$ Leu $\left(\mathrm{mmols}\right.$ Leu $\left.\mathrm{L}^{-1} \mathrm{~h}^{-1}\right) \times 131.2$ $\times(\% \text { Leu })^{-1} \times($ C:Protein $) \times$ ID $)$; with C:protein $=0.86$ (ratio of cellular carbon to protein); \%Leu $=0.073$ (fraction of leucine in protein). ID = 1 (Isotopic Dilution); $131.2=$ Molecular weight of the leucine.

\section{Estimation of viral production}

We used the dilution technique of Wilhelm et al. [63] in order to estimate the viral production throughout the experiment at day 0,2 and $4.50 \mathrm{ml}$ of sub-samples were diluted and mixed with $100 \mathrm{ml}$ of virus-free $(0.02-$ $\mu \mathrm{m}$ pore size pre-filtered at day 0 and kept at $4^{\circ} \mathrm{C}$ ) lake water, and incubated in dark conditions. Triplicates 
were made and incubated at in situ temperature in the dark. One-ml sub-samples were collected at $0,3,6,12$, 18 and $24 \mathrm{~h}$. Viral production rates were determined from first-order regressions of viral abundance versus time after correcting for the dilution of the bacterial hosts between the samples and the natural community, a necessary step to account for the loss of potentially infected cells during the filtration. Viral production (VP, virus $\mathrm{ml}^{-1} \mathrm{~h}^{-1}$ ) was calculated as proposed by Hewson and Fuhrman [64]: VP $=m \times(b / B)$ where $m$ is the slope of the regression line, $\mathrm{b}$ the concentration of bacteria after dilution, and $\mathrm{B}$ the concentration of bacteria prior to dilution.

We estimated the number of lysed bacteria (cell ml ${ }^{-1}$ $\mathrm{h}^{-1}$ ) during the viral lysis activity by considering an average burst size (27) previously estimated for Lake Bourget $[7,65]$ with the number of lysed bacteria $=$ Viral production/Burst Size [66].

In order to show the effect of the presence of flagellates on the dynamics and activities of both heterotrophic bacteria and viruses, we calculated the stimulation of the different parameters presented above (both abundance and production) in treatments VF and VFA (as proposed by Bonilla-Findji et al. [18] and Zhang et al. [22]). The stimulation corresponds to the difference in variation between treatments with flagellates (VFA or VF treatments) and the treatment without flagellates ( $\mathrm{V}$ treatment) between 0 and $48 \mathrm{~h}$, and between $48 \mathrm{~h}$ and $96 \mathrm{~h}$, respectively. As an example, the equation used to calculate the stimulation of bacterial abundance in the VF treatment, between 0 and $48 \mathrm{~h}$, is:

$$
\text { Stimulation }_{\mathrm{BA}}(\%)=\left(\frac{\mathrm{BA}_{(\mathrm{VFA}) 48}}{\mathrm{BA}_{(\mathrm{V}) 48}} \times 100\right)-\left(\frac{\mathrm{BA}_{(\mathrm{VFA}) 0}}{\mathrm{BA}_{(\mathrm{V}) 0}} \times 100\right)
$$

Where $\mathrm{BA}_{(\mathrm{VFA}) 0}$ and $\mathrm{BA}_{(\mathrm{VFA}) 48}$ are the abundance of bacteria in VFA, at the beginning and after $48 \mathrm{~h}$ of incubation and $\mathrm{BA}_{(\mathrm{V}) 0}$ and $\mathrm{BA}_{(\mathrm{V}) 48}$ are the abundance of bacteria in $\mathrm{V}$, at the beginning and after $48 \mathrm{~h}$ of incubation.

\section{Net growth and loss rates of bacteria}

Bacterial net growth rates with bacterial predators ( $\mathrm{rb}$, $\left.\mathrm{d}^{-1}\right)$ and without predators $\left(\mathrm{r}, \mathrm{d}^{-1}\right)$ were calculated from the difference in abundances from day 0 to day 2 $(\mathrm{t}=48 \mathrm{~h})$ and from day 0 and day $4(\mathrm{t}=96 \mathrm{~h})$, assuming exponential growth. We used the equations: $r b=$ $(\ln \mathrm{Nbt}-\ln \mathrm{Nb0}) / \mathrm{t}$ and $\mathrm{r}=(\ln \mathrm{Nt}-\ln \mathrm{N} 0) / \mathrm{t}$; where $\mathrm{NO}$ and $\mathrm{Nt}$ are the bacterial abundances $(\mathrm{Nb} 0, \mathrm{Nbt}=$ with predators $(\mathrm{VFA}, \mathrm{VF}), \mathrm{N} 0, \mathrm{Nt}=$ without predators $(\mathrm{V}))$ at the beginning and after $48 \mathrm{~h}$ or $96 \mathrm{~h}$ of incubation. The loss rate of bacteria due to grazing activities were calculated as the differences between the treatment with (VFA, VF) and without $(\mathrm{V})$ predators: $\mathrm{g}=\mathrm{r}$ - rb [67].

\section{Nucleic acid extraction, PCR and DGGE}

Analysis of the bacterial community structure was assessed using Denaturing Gradient Gel Electrophoresis (DGGE). Bacteria were harvested from approximately $250 \mathrm{ml}$ water onto $47-\mathrm{mm}$ diameter, $0.2-\mu \mathrm{m}$ pore size, polycarbonate white membrane filters (Nuclepore) after a pre-filtration step through $2-\mu \mathrm{m}$ pore size polycarbonate membrane filters (Nuclepore) to eliminate large eukaryotes and filamentous cyanobacteria. The filters were then stored at $-80^{\circ} \mathrm{C}$ prior to nucleic acid extraction. Nucleic acid extraction was performed as described in Dorigo et al. [68]. Molecular weight distribution and purity of the DNA were assessed by $1 \%$ agarose gel electrophoresis and quantified by both visual comparison with molecular weight markers in ethidium bromide stained agarose gels (rough estimate) and by optical density measurements using NanoDrop ND-1000 Spectrophotometer (Thermo Scientific). Such material was then stored at $-20^{\circ} \mathrm{C}$ until PCR amplification.

PCR reactions were carried out using the Eubacteriaspecific primer 358-GC [47] and the universal primer $907 \mathrm{rM}$ [69] which amplify the variable V3 region of the 16S rRNA gene and yield a DNA fragment of ca. 550 bp. All PCR amplifications were carried out using about 30 ng of extracted DNA in a $50 \mu \mathrm{l}$ reaction mix containing $10 \times T a q$ reaction buffer (Eurobio), $1.5 \mathrm{mM} \mathrm{MgCl}_{2}$, $120 \mu \mathrm{M}$ of each deoxynucleotide, $1 \mu \mathrm{M}$ of each primer, bovine serum albumin (Sigma, $0.5 \mathrm{mg} \mathrm{ml}^{-1}$ final concentration), and 1.25 U Taq DNA polymerase (Eurobluetaq, Eurobio). PCR amplification consisted of an initial denaturation step of $94^{\circ} \mathrm{C}$ for $5 \mathrm{~min}$, followed by 30 cycles of denaturation at $94^{\circ} \mathrm{C}$ for $1 \mathrm{~min}$, annealing at $52^{\circ} \mathrm{C}$ for 1 $\mathrm{min}$, and extension at $72^{\circ} \mathrm{C}$ for $1 \mathrm{~min}$, and a final elongation step at $72^{\circ} \mathrm{C}$ for $5 \mathrm{~min}$ using a PTC100 thermocycler (MJ Research). Correct size (ca. 500 bp length) of PCR products were determined by $2 \%$ agarose gel electrophoresis with a DNA size standard (Low DNA Mass Ladder, GIBCO BRL).

DGGE analysis was performed on PCR fragments, as described in Berdjeb et al. [57] using Ingenyphor $U-2^{\circledR}$ (Ingeny international) and by using a $40-80 \%$ gradient. Since all of the replicates (more than 70) could not be placed in the same gel, aliquots of DNA extracts from the three replicates of each treatment were pooled, but only after we had checked similarity in DGGE patterns between replicates for all sampling time points. Digital images of the gels were obtained using a Kodak DC290 camera, and were then saved for further analysis using the Microsoft Photo Editor Software. The DGGE banding patterns were analyzed using the GelCompare II software package (Applied Maths, Kortrijk, Belgium) and after digitalization of the DGGE gels. Briefly, banding patterns were first standardized with a reference pattern included in all gels. Each band was 
described by its position ( $\mathrm{Y}$, in pixel on the image file) and its relative intensity in the profiles $\left(P_{i}\right)$ which could be described as the ratio between the surface of the peak $\left(\mathrm{n}_{\mathrm{i}}\right)$ and the sum of the surfaces for all the peaks within the profile $(\mathrm{N})$.

\section{Cloning-sequencing}

From the DGGE gels, the bands of interest were excised, placed in sterile water and stored at $-20^{\circ} \mathrm{C}$. Prior to cloning, each excised DGGE band was subjected to a freeze-thaw cycle and then centrifuged. DGGE fragments contained in the supernatant were used as template in a second PCR amplification performed as described above. The resulting PCR products were cloned with an Invitrogen cloning kit (TOPO TA cloning) according to the manufacturer's instructions. Twelve clones were randomly chosen for each band of interest. Each clone was verified by PCR using the commercial primers M13 and finally sequenced (GATC Biotech). Sequences were then edited, aligned with Genedoc [70] and finally checked for chimeras using Bellerophon [71] and the Ribosomal Database Project (RDP) [72]. Sequences were finally subjected to BLAST and the RDP database to determine the level of similarity with other $16 \mathrm{~S}$ rRNA gene sequences available in Genbanks.

\section{Statistical Analysis}

Differences between treatments per experiment, per time point were tested for significance using parametric analysis of variance (ANOVA) including post hoc test analysis (Fisher's protected least significant difference test). Testing for normality and homogeneity of variance was performed, and data transformation was done when required (for all data compared per test). Differences were considered significant at $\mathrm{P}$ value of $<0.05$. We compared the difference on the stimulation rate of abundance and production of both viral and bacterial communities according to the seasons $(\mathrm{n}=12)$ and trophic status $(\mathrm{n}=24)$ by using paired $\mathrm{t}$ test.

\section{Acknowledgements and funding}

We thank J.C. Hustache, P. Chifflet, and P. Perney for technical assistance in sampling, B. Leberre for help in molecular analyses and J. Kirkman for correcting and improving the English version of the revised form of the manuscript. L. Berdjeb was financed by a French-Algerian cooperation fellowship completed by INRA. This study is a contribution to the ANR AQUAPHAGE project.

\section{Authors' contributions}

All authors read and approved the final manuscript. SJ was the responsible of this study and participated in the experimental design. LB realised all analyses except for the flagellate counting and phylotype analysis. TP made the cloning-sequencing analysis of the selected DGGE bands. ID participated to the experimental design and realised the flagellate counting. Writing was mainly done by LB, helped and corrected by ID and SJ.

\section{Authors' information}

LB and TP have been PhD students, working in the BioFEEL group between 2007 and early 2011. ID and SJ have obtained permanent positions since 2000, as research scientists.

Received: 13 October 2010 Accepted: 29 April 2011

Published: 29 April 2011

\section{References}

1. Sanders RW, Porter KG, Bennett SJ, DeBiase AE: Seasonal patterns of bacterivory by flagellates, ciliates, rotifers and cladocerans in a freshwater planktonic community. Limnol Oceanogr 1989, 34:673-687.

2. Pernthaler J: Predation on Procaryotes in the water column and its ecological implications. Nat Rev Microbiol 2005, 3:537-546.

3. Pomeroy LR: The ocean's food web, a changing paradigm. BioSci 1974 9:499-504.

4. Pace ML, McManus GB, Findlay SE: Planktonic community structure determines the fate of bacterial production in temperate lake. Limnol Oceanogr 1990, 35:795-808.

5. Gasol JM, Pedro-Alio C, Vaqué D: Regulation of bacterial assemblages in oligotrophic plankton systems: results from experimental and empirical approaches. Anton Leeuw 2002, 81:435-452.

6. Kritzberg ES, Langenheder S, Lindström ES: Influence of dissolved organic matter source on lake bacterioplankton structure and function implications for seasonal dynamics of community composition. FEMS Microbiol Ecol 2006, 56:406-417.

7. Jacquet S, Domaizon I, Personnic S, Duhamel S, Pradeep Ram AS, Heldal M, Sime-Ngando T: Estimates of protozoan and virus-mediated mortality of bacterioplankton in Lake Bourget (France). Freshwater Biol 2005, 50:627-645.

8. Comte J, Jacquet S, Viboud S, Fontvieille D, Millery A, Paolini G, Domaizon I: Microbial community structure and dynamics in the largest natural French lake (Lake Bourget). Microb Ecol 2006, 52:72-89.

9. Hahn $M$, Höfle M: Grazing of protozoa and its effect on population of aquatic bacteria. FEMS Microbiol Ecol 2001, 35:113-121.

10. Bouvier T, Del Giorgio P: Key role of selective viral-induced mortality in determining marine bacterial community composition. Environ Microbiol 2007, 9:287-297.

11. Weinbauer MG: Ecology of prokaryotic viruses. FEMS Microbiol Rev 2004, 28:127-181.

12. Middelboe M: Microbial disease in the sea: effects of viruses on marine carbon and nutrient cycling. In Infectious Disease Ecology: Effects of Ecosystems on Disease and of Disease on Ecosystems. Edited by: Ostfeld RS, Keesing F, Eviner VT. Princeton University Press, Princeton NJ; 2008:242-259.

13. Fuhrman JA: Marine viruses: biogeochemical and ecological effects. Nature 1999, 399:541-548.

14. Wilhelm SW, Suttle CA: Viruses and nutrient cycles in the Sea. Bioscience 1999, 49:781-788.

15. Azam F, Fenchel T, Field JG, Gary JS, Meyer-Reil LA, Thingstad F: The ecological role of water-column microbes in the sea. Mar Ecol Prog Ser 1983, 10:257-263.

16. Bratbak G, Thingstad TF, Heldal M: Viruses and the microbial loop. Microb Ecol 1994, 28:209-221.

17. Weinbauer MG, Rassoulzadegan F: Are viruses driving microbial diversification and diversity? Environ Microbiol 2004, 6:1-11.

18. Bonilla-Findji O, Herndl GJ, Gattuso JP, Weinbauer MG: Viral and Flagellate Control of Prokaryotic Production and Community Structure in Offshore Mediterranean Waters. Appl Environ Microbiol 2009, 75:4801-4812.

19. Šimek K, Pernthaler J, Weinbauer MG, Hornak K, Dolan JR, Nedoma J, Masin M, Amann R: Changes in bacterial community composition and dynamics and viral mortality rates associated with enhanced flagellate grazing in a mesoeutrophic reservoir. Appl Environ Microbiol 2001, 67:2723-2733.

20. Jürgens K, Pernthaler J, Schalla S, Amann R: Morphological and compositional changes in a planktonic bacterial community in response to enhanced protozoan grazing. Appl Environ Microbiol 2002, 65:1241-1250.

21. Weinbauer MG, Hornak K, Jezbera J, Nedoma J, Dolan JR, Simek K Synergistic and antagonistic effects of viral lysis and protistan grazing on bacterial biomass, production and diversity. Environ Microbio/ 2007, 9:777-788 
22. Zhang R, Weinbauer MG, Qian PY: Viruses and flagellates sustain apparent richness and reduce biomass accumulation of bacterioplankton in coastal marine waters. Environ Microbiol 2007, 9:2008-2018.

23. Sime-Ngando T, Pradeep Ram AS: Grazer effects on prokaryotes and viruses in a freshwater microcosm experiment. Environmental Microbiology 2005, 13:616-630.

24. Personnic S, Domaizon I, Sime-Ngando T, Jacquet S: Seasonal variations of microbial abundances and virus- versus flagellate-induced mortality of picoplancton in three peri-alpine lakes. J Plankt Res 2009, 31:1161-1177.

25. Personnic S, Domaizon I, Dorigo U, Berdjeb L, Jacquet S: Seasonal and spatial variability of virio-, bacterio- and picophytoplankton in three peri-alpine lakes. Hydrobiol 2009, 627:99-116.

26. Pradeep Ram AS, Sime-Ngando T: Functional responses of prokaryotes and viruses to grazer effects and nutrient additions in freshwater microcosms. The ISME Journal 2008, 2:498-509.

27. Jacquet S, Domaizon I, Personnic S, Sime-Ngando T: Do small grazers influence viral induced bacterial mortality in Lake Bourget? Fund Appl Limnol 2007, 170:125-132.

28. Miki T, Yamamura N: Intraguild predation reduces bacterial species richness and loosens the viral loop in aquatic systems: 'kill the killer of the winner' hypothesis. Aquat Microb Ecol 2005, 40:1-12.

29. Miki T, Jacquet $\mathrm{S}$ : Complex interactions in the microbial world: underexplored key links between viruses, bacteria and protozoan grazers in aquatic environments. Aquat Microb Ecol 2008, 51:195-208.

30. Hornak K, Masin M, Jezbera J, Bettarel Y, Nedoma J, Sime-Ngando T, Simeck K: Effects of decreased resource availability, protozoan grazing and viral impact on a structure of bacterioplankton assemblage in a canyon-shaped reservoir. FEMS Microbiol Ecol 2005, 52:315-327.

31. Manage PM, Kawabata Z, Nakano S, Nishibe Y: Effect of heterotrophic nanoflagellates on the loss of virus-like particles in pond water. Ecol Res 2002, 17:473-479.

32. Thomas R, Berdjeb L, Sime-Ngando $T$, Jacquet $S$ : Viral abundance, production, decay rates, and life strategies (lysogeny vs. lysis) in Lake Bourget (France). Environ Microbiol

33. Weinbauer MG, Brettar I, Höfle M: Lysogeny and virus induced mortality of bacterioplankton in surface, deep, and anoxic marine waters. Limnol Oceanogr 2003, 48:1457-1465

34. Lymer D, Lindstrom ES, Vrede K: Changing importance of viral induced bacterial mortality in lakes along gradients in trophic status and humic content. Freshwater Biol 2008, 53:1101-1113.

35. Wilson WH, Turner S, Mann NH: Population dynamics of phytoplankton and viruses in a phosphate limited mesocosm and their effect on DMSP and DMS production. Estuar Coast Shelf Sci 1998, 46:49-59.

36. Bongiorni M, Magagnini M, Armeni M, Noble RT, Danovaro R: Viral Production, Decay Rates, and Life Strategies along a Trophic Gradient in the North Adriatic Sea. Appl Environ Microbiol 2005, 71:6644-6650.

37. Suttle CA, Cheng F: Mechanisms and rates of decay of marine viruses in seawater. Appl Environ Microbiol 1992, 58:3721-3729.

38. Bettarel $Y$, Sime-Ngando T, Bouvy M, Arfi R, Amblard C: Low consumption of virus-sized particles by heterotrophic nanoflagellates in two lakes of French Massif Central. Aquat Microb Ecol 2005, 39:205-209.

39. Domaizon I, Viboud S, Fontvieille D: Taxon-specific and seasonal variations in flagellates grazing on heterotrophic bacteria in the oligotrophic Lake Annecy - importance of mixotrophy. FEMS Microbio Ecol 2003, 46:317-329.

40. Pace ML, Bailif MD: Evaluation of a fuorescent microsphere technique for measuring grazing rates of phagotrophic microorganisms. Mar Ecol Prog Ser 1987, 40:185-193.

41. Fenchel T: Ecology of Protozoa: The Biology of Free-living Phagotrophic Protists. Science Tech., Springer, Berlin; 1987, 197.

42. Jugnia LB, Tadonléké RD, Sime-Ngando T, Devaux J: The Microbial Food Web in the Recently Flooded Sep Reservoir: Diel Fluctuations in Bacterial Biomass and Metabolic Activity in Relation to Phytoplankton and Flagellates Grazers. Microb Ecol 2000, 40:317-329.

43. Gasol JM, Del Giorgio PA: Using flow cytometry for counting natural planktonic bacteria and understanding the structure of planktonic bacterial communities. Sci Mar 2000, 64:197-224.

44. Lebaron P, Servais P, Baudoux AC, Bourrain M, Courties C, Parthuisot N: Variations of bacterial-specific activity with cell size and nucleic acid content assessed by flow cytometry. Aquat Microb Ecol 2002, 28:131-140.
45. Pernthaler J, Simek K, Sattler B, Schwarzenbacher A, Bobkova J, Psenner R: Short-term changes of protozoan control on autotrophic picoplankton in an oligo-mesotrophic lake. J Plank Res 1996, 18:443-462.

46. Sherr EB, Sherr BF: Significance of predation by protists in aquatic microbial food webs. Anton Leeuw 2002, 81:293-308.

47. Muyzer G, de Waal EC, Uitterlinden AG: Profiling of complex microbial populations by denaturating gradient gel electrophoresis analysis of polymerase chain reaction-amplified genes coding for 16S rRNA. Appl Environ Microbiol 1993, 59:695-700.

48. Casamayor EO, Schäfer H, Bañeras L, Pedrós-Aliós C, Muyzer G: Identification of spatio-temporal differences between microbial assemblages from two neighboring sulfurous lakes: comparison by microscopy and denaturing gradient gel electrophoresis. Appl Environ Microbiol 2000, 66:499-508.

49. Von Wintzingerode F, Goebel UB, Stackebrandt E: Determination of microbial diversity in environmental samples: pitfalls of PCR based rRNA analysis. FEMS Microbiol Rev 1997, 21:213-229.

50. Humbert JF, Dorigo U, Cecchi P, LeBerre B, Debroas D, Bouvy M: Comparison of the structure and composition of bacterial communities from temperate and tropical freshwater ecosystems. Environ Microbiol 2009, 11:2339-2350.

51. Debroas D, Humbert JF, Enault F, Bronner G, Faubladier M, Cornillot E: Metagenomic approach studying the taxonomic and functional diversity of the bacterial community in a mesotrophic lake (Lac du Bourget, France). Environ Microbiol 2009, 11:2412-2424.

52. Schwalbach MS, Hewson I, Fuhrman JA: Viral effects on bacterial community composition in marine plankton microcosms. Aquat Microb Ecol 2004, 34:117-127.

53. Winter C, Smit A, Herndl GJ, Weinbauer MG: Impact of virioplankton on archaeal and bacterial community richness as assessed in seawater batch cultures. Appl Environ Microbiol 2004, 70:803-813.

54. Hewson I, Fuhrman JA: Viral impacts upon marine bacterioplankton and sediment bacterial assemblage composition. J Mar Biol Assoc UK 2006, 86:577-589.

55. Šimek K, Hornák K, Mašín M, Christaki U, Nedoma J, Weinbauer M, Dolan J: Comparing the effects of resource enrichment and grazing on a bacterioplankton community of a meso-eutrophic reservoir. Aquat Microb Ecol 2003, 31:123-135.

56. Šimek K, Nedoma J, Pernthaler J, Posch T, Dolan JR: Altering the balance between bacterial production and protistan bacterivory triggers shifts in freshwater bacterial community composition. Anton Leeuw 2002, 81:453-463.

57. Berdjeb L, Ghiglione JF, Domaizon I, Jacquet S: A two-year assessment of the main environmental factors driving the free-living bacterial community structure in lake Bourget (France). Microbial Ecology 61:941-954.

58. Vaulot D: CytoPC: processing software for flow cytometric data. Signal Noise 1989, 2:8.

59. Caron DA: Technique for enumeration of heterotrophic and phototrophic nanoplankton, using epifluorescence microscopy, and comparison with other procedure. Appl Environ Microbiol 1983, 46:491-498

60. Bloem J, Bar-Gilissen MJB, Carpenter TE: Fixation, counting, and manipulation of heterotrophic nanoflagellates. App/ Environ Microbio/ 1986, 52:1266-1272.

61. Kirchman DL: Leucine incorporation as a measure of biomass production by heterotrophic bacteria. In Handbook of methods in aquatic microbial ecology. Edited by: Kemp PF, Sherr BF, Sherr EB, Cole JJ. Boca Raton: Lewis; 1993:509-512.

62. Simon M, Azam F: Protein content and protein synthesis rates of planktonic bacteria. Mar Ecol Prog Ser 1989, 51:201-213.

63. Wilhelm SW, Brigden SM, Suttle CA: A dilution technique for the direct measurement of viral production: A comparison in stratified and tidally mixed coastal waters. Microb Ecol 2002, 43:168-173.

64. Hewson I, Fuhrman JA: Covariation of viral parameters with bacterial assemblage richness and diversity in the water column and sediments. Deep-Sea Res / 2007, 54:811-830.

65. Sime-Ngando T, Colombet J, Personnic S, Domaizon I, Dorigo U, Perney P, Hustache JC, Viollier E, Jacquet S: Short-term variations in abundances and potential activities of viruses, bacteria and nanoprotists in Lake Bourget. Ecol Res 2008, 23:851-861. 
66. Weinbauer MG, Rowe JM, Wilhelm SW: Determining rates of virus production in aquatic systems by virus reduction approach. MAVE 2010, 1:1-8.

67. Del Giorgio PA, Gasol JM, Vaqué D, Mura P, Agusti S, Duarte CM: Bacterioplankton community structure: protists control net production and the proportion of active bacteria in a coastal marine community. Limnol Oceanogr 1996, 41:1169-1179.

68. Dorigo U, Fontvieille D, Humbert JF: Spatial variability in the abundance and composition of the free-living bacterioplankton community in the pelagic zone of Lake Bourget (France). FEMS Microbiol Ecol 2006, 58:109-119.

69. Schauer M, Balagué V, Pedrós-Alió C, Massana R: Seasonal changes in the taxonomic composition of bacterioplankton in coastal oligotrophic system. Aquat Microb Ecol 2003, 31:163-174.

70. Nicholas KB, Nicholas HBJ: Genedoc: a tool for editing and annoting multiple sequence alignments. 1997, Distributed by the author. [Online] (http://ww.cris.com/ketchup/genedoc.shtml).

71. Huber T, Faulkner G, Hugenholtz P: Bellerophon: a program to detect chimeric sequences in multiple sequence alignments. Bioinformatics Applications Note 2004, 20.

72. Cole JR, Chai B, Farris RJ, Wang Q, Kulam SA, McGarrell DM, Garrity GM, Tiedje JM: The Ribosomal Database Project (RDP-II): sequences and tools for high-throughput rRNA analysis. Nucl AC Res 2005, , 33 Database: D294-296.

doi:10.1186/1471-2180-11-88

Cite this article as: Berdjeb et al:: Effect of grazers and viruses on bacterial community structure and production in two contrasting trophic lakes. BMC Microbiology 2011 11:88.

\section{Submit your next manuscript to BioMed Central and take full advantage of:}

- Convenient online submission

- Thorough peer review

- No space constraints or color figure charges

- Immediate publication on acceptance

- Inclusion in PubMed, CAS, Scopus and Google Scholar

- Research which is freely available for redistribution

Submit your manuscript at www.biomedcentral.com/submit 